\title{
Biomass Production with Willow and Poplar Short Rotation Coppices on Sensitive Areas - the Impact on Nitrate Leaching and Groundwater Recharge in a Drinking Water Catchment near Hanover, Germany
}

\author{
Paul Schmidt-Walter • \\ Norbert P. Lamersdorf \\ Published online: 12 July 2012 \\ (C) The Author(s) 2012. This article is published with open access at Springerlink.com
}

\begin{abstract}
In a lowland drinking water catchment area, nitrate leaching as well as groundwater recharge (GWR) was investigated in willow and poplar short rotation coppice (SRC) plantations of different ages, soil preparation measures prior to planting and harvesting intervals. Significantly increased nitrate concentrations of $16.6 \pm 1.6 \mathrm{mg} \mathrm{NO}_{3}-\mathrm{N} \mathrm{L}^{-1}$ were measured in winter/spring 2010 on a poplar site, established in 2009 after deep plowing $(90 \mathrm{~cm})$ but then, subsequently decreased strongly to below $2 \mathrm{mg} \mathrm{NO}_{3}-\mathrm{N} \mathrm{L}^{-1}$ in spring 2011. The fallow ground reference plot showed nitrate concentrations consistently below $1 \mathrm{mg} \mathrm{L}^{-1}$ and estimated annual seepage output loss was only $1.36 \pm 1.1 \mathrm{~kg} \mathrm{ha}^{-1} \mathrm{a}^{-1}$. Leaching loss from a neighboring willow plot from 2005 was $14.3 \pm$ $6.6 \mathrm{~kg} \mathrm{NO}_{3}-\mathrm{N} \mathrm{ha}^{-1}$ during spring 2010 but decreased to $2.0 \pm$ $1.5 \mathrm{~kg} \mathrm{NO}_{3}-\mathrm{N} \mathrm{ha}^{-1}$ during the subsequent drainage period. A second willow plot, not harvested since its establishment in 1994, showed continuously higher nitrate concentrations $\left(10.2 \pm 1.7 \mathrm{NO}_{3}-\mathrm{N} \mathrm{L}^{-1}\right)$, while a neighboring poplar plot, twice harvested since 1994 showed significantly reduced nitrate concentrations. Water balance simulations, referenced by soil water tension and throughfall measurements, showed that at $655 \mathrm{~mm}$ annual rainfall, GWR from the reference plot (300 $\mathrm{mm} \mathrm{a}^{-1}$ ) was reduced by $40 \%$ (to $180 \mathrm{~mm} \mathrm{a}^{-1}$ ) on the 2005 willow stand, mainly due to doubled rainfall interception losses. However, transpiration was limited by low soil water storage capacities, which in turn led to a moderate impact on GWR. We conclude that well-managed SRC on sensitive areas can prevent nitrate leaching, while impacts on GWR may be mitigated by management options.
\end{abstract}

P. Schmidt-Walter $(\bowtie) \cdot$ N. P. Lamersdorf

Büsgen-Institute, Soil Science of Temperate Ecosystems,

Georg-August-Universität Göttingen,

Büsgenweg 2,

37077 Göttingen, Germany

e-mail: pschmid1@gwdg.de
Keywords SRC · Groundwater quality · Sandy soil · Evapotranspiration · Leaf area index

\section{Introduction}

To combat climate change and improve security of energy supply, bioenergy derived from forestry and agriculture plays a key role in the European Union (EU). Bioenergy production has almost doubled in production in the last 15 years and currently supplies $7 \%$ of the total EU primary energy [1]. According to the binding targets set by the EU Renewable Energy Directive (RED), all Member States should strive to a $20 \%$ share of renewable energy by 2020. Furthermore, it is required that EU member states achieve at least a $10 \%$ share of renewable energy (biofuel) of the total gasoline and diesel consumed in the transport sector by the year 2020 [2].

Bioenergy crops from agriculture provide the largest potential to fulfill those EU targets. An assessment made by the European Environment Agency found that about $85 \%$ of the potential bioenergy supply can be produced by only seven member states (Spain, France, Germany, Italy, UK, Lithuania and Poland; [3]). To achieve these goals, approximately 17.5 million ha of land will have to be dedicated to the production of energy crops by 2020 [4]. Thus, an additional pressure on farmland biodiversity as well as on soil and water resources can be expected in biofuel production regions in the EU.

In Germany, approximately 2.3 million ha or $19 \%$ of the crop land is already being used for the production of renewable raw materials [5]. Compared to 2001, the area has almost tripled and in 2011 the largest proportion of about 2 million ha fell to the energy plant production with a share of $46 \%$ for biodiesel (mainly canola), $41 \%$ for biogas 
(mainly maize) and $13 \%$ for the production of bioethanol. Although perennial energy crops like short rotation coppices (SRC) with fast-growing trees have played only a minor role in bioenergy production, the total cultivated area for SRC increased from about 4,000 ha in 2010 to about 5,000 ha in just 1 year [5].

Nevertheless, SRC may provide unique ecological services that warrant consideration. As a result of lower fertilizer requirements as well as a higher $\mathrm{N}$-use efficiency due to effective N-recycling, SRC emit 40 to $>99 \%$ less $\mathrm{N}$ than conventional annual crops. Furthermore, SRC have the potential to sequester additional carbon $(0.44 \mathrm{Mg}$ soil $\mathrm{C} \mathrm{ha}{ }^{-1}$ year $^{-1}$ ) in soils if established on former cropland [6]. According to Djomo et al. [7], SRC yielded about 1486 times more energy than coal per unit of fossil energy input and greenhouse gas (GHG) emissions were 9-161 times lower than those of coal. Consequently, SRC provide an opportunity to reduce dependency on fossil fuels and to mitigate GHG emissions. Therefore, SRC should be part of an overall strategy for achieving the minimum target for GHG emissions reduction as required by the EU RED [7]. Additionally, SRC may also increase agricultural income diversification, enhance biodiversity, and reduce nutrient losses to the groundwater [6].

However, as the area requirements for bioenergy feedstock production increases, the pressure on marginal sites or fallow grounds with unfavorable site conditions may increase and SRC systems applied here may also have negative environmental impacts. Most importantly, it seems that SRC plots have to be optimally prepared by plowing to guarantee weed control during crop establishment [8-10]. Especially on fallow grounds, this may lead to an extra emission of $\mathrm{CO}_{2}$ and $\mathrm{N}_{2} 0$. According to Djomo et al. [7], these impacts depend on various factors such as the SRC cultivation practice, land management, site conditions, downstream processing and distribution routes. Furthermore, indirect impacts have to be considered. For instance, $\mathrm{N}_{2} \mathrm{O}$ emissions as a direct impact may be low on welldrained and well-aerated soils, but $\mathrm{NO}_{3}$ leaching may occur instead and contaminate adjacent water bodies $[6,11,12]$.

Accordingly, the given study is focusing on such indirect emission effects, i.e., the risk of nitrate leaching during the establishment of SRC plantations, and the potential of nitrogen binding after the cultivation of SRC on fallow ground.

Our study site was located in the most important drinking water catchment area of the city of Hanover, Germany ("Fuhrberger Feld"). Here, much effort was spent by the water authorities during the last decades to keep the average seepage nitrate concentration on the catchment level below the legal drinking water threshold value of $10.3 \mathrm{mg} \mathrm{NO}_{3}-\mathrm{N} \mathrm{L}^{-1}$. Part of these efforts were voluntary agreements with resident farmers to reduce fertilizer applications to a minimum, but also many fields were set aside to lie fallow.
The enhanced nitrate concentrations in the seepage output of Fuhrberger Feld are linked to the prevailing periglacial and sandy soils in the area and the historical land use. With the formerly widespread heath plaggen fertilization process, high amounts of carbon were brought into the sandy soils [13]. In combination with originally high groundwater levels and pasture as predominant land use, high amounts of soil organic carbon accumulated in the topsoils of these areas. As long as these site conditions persisted (i.e., no changes in the water table or the grassland cover) those carbon stocks remained more or less stable. However, since the 1960s, a significant increase of the drinking water demand of the city of Hanover lowered the groundwater table considerably, with the result that the wet grassland fell dry. This lowering of the groundwater table and the subsequent transfer of grassland into intensively used arable land initiated a strong mineralization process, including the transfer of organic $\mathrm{N}$ to nitrate. According to model calculations of Springob et al. [14] and Springob and Kirchmann [15], it was estimated that it might take up to 100 years for the soils to achieve a new equilibrium under the present conditions. Under these conditions, Köhler et al. [16] concluded that the only way to reduce the $\mathrm{N}$ output to groundwater is to convert the arable land into forests or back into continuous grasslands, while setting aside the land will not reduce the risk of nitrate leaching in the long run. However, another promising land-use for fallow grounds to meet the requirements of groundwater protection might be the establishment of SRC with fast-growing trees like poplar or willow.

The desired positive effect of reducing nitrate leaching losses by SRC might come along with negative effects on groundwater quantity, as higher rates of transpiration and interception evaporation can be anticipated [17-24]. In a review [25], Dimitriou et al. summarized that groundwater recharge rates from SRC stands in general are expected to be lower when compared to arable fields or grassland in the same region. Moreover, there is indication that the amount of reduction beyond precipitation strongly depends on sitespecific conditions like soil type, occurrence of drought periods during the growing season and management practices such as the harvesting interval.

Biomass production by SRC might thus conflict with the assigned land use purpose in Fuhrberger Feld, i.e., to provide and guarantee adequate amounts of good quality drinking water for the city of Hanover.

Within this context, the objectives of our study were to evaluate the impact of SRC cultivation on (1) nitrate leaching losses and (2) groundwater recharge, by giving initial insights into basic soil background conditions, seepage nitrate concentrations and water budgets of four SRC stands (two willow and two poplar SRCs) in comparison with a fallow ground reference site. The studied SRC stands differ 
in stand age, soil preparation measures and harvesting regimes. Water balance components are calculated by applying a soil vegetation atmosphere transport model (CoupModel [26]) to the reference site and a willow SRC established in 2005. The simulations are parameterized with results from field measurements; the model performance is checked by observed soil water tensions and stand precipitation. Finally, we estimate nitrate seepage output rates by combining simulated drainage flux with measured nitrate concentrations. The following questions will be addressed: Is a change in land use from fallow ground to SRC associated with increased $\mathrm{N}$ leaching rates? Which factors control $\mathrm{N}$ leaching rates? Under present site conditions, does a probable reduction in groundwater recharge interfere with the production of drinking water? How do site and vegetation characteristics affect the water balance and what management options do we have to mitigate a negative impact on groundwater recharge?

\section{Material and Methods}

\section{Site and Research Plot Description}

The Fuhrberger Feld drinking water catchment is located in northwest Germany, approximately $30 \mathrm{~km}$ north of the city of Hanover and has a size of $308 \mathrm{~km}^{2}$. Within this catchment area, research plots are located northwest of the village Fuhrberg $\left(52^{\circ} 36^{\prime} \mathrm{N}, 9^{\circ} 51^{\prime} \mathrm{E}\right)$ in a level 2 drinking water sanctuary [27] at an elevation of $41 \mathrm{~m}$ asl. Average annual precipitation (1971-2000) is $670 \mathrm{~mm}$, of which $46 \%$ fall during the growing season (May-October) and the mean annual temperature is $9.2^{\circ} \mathrm{C}$.

Table 1 shows the basic site characteristics of the research plots. There are two older poplar and willow plots, planted in 1994 (P94/30 and W94/30), a younger willow plot from $2005(\mathrm{~W} 05 / 90)$ and a poplar plot from 2009 (P09/90). A setaside fallow ground serves as reference site (Ref). Prior to planting, P94/30 and W94/30 were conventionally plowed to $30 \mathrm{~cm}$ soil depth. The former organic topsoil horizon (Ah) was changed to an Ap (plowed) horizon, while the rest of the horizon sequence remained unchanged and comparable to the reference site (Ref; $E=$ eluviation horizon due to Plaggen fertilization [13], Bv-rGo=typical cambisol horizon, including indications of relict (r) reduced and gleyic conditions (Gor, Gr) due to a former higher groundwater table, mixed with the $\mathrm{Cv}$ horizon).

Prior to SRC cultivation from cuttings, plots Ref, P09/90 and W05/90 were part of one single arable field, which was set aside for groundwater protection reasons in the early 1990s. The Ref plot is dominated by grasses and some scattered flowers, due to the long time of abandonment. Plots W05/90 and P09/90 were deeply plowed to a maximum soil depth of $90 \mathrm{~cm}$. As a result, the Ah layer and its seedbank, as found on Ref, was buried at a depth of 30 $60 \mathrm{~cm}$ (R2+E horizon) and covered with sandy bedrock material (R1). The site preparation allowed willow cuttings a headstart over the competing grasslayer, which is now present in the field. In 2010, the tree mortality rate on W05/90 was $1.7 \%$ [28]. During the study period, several plots were harvested. In March 2010, W94/30 was coppiced for the first time since its establishment in 1994, in April 2011 W05/90 followed. P94/30 was cut in March 2011 for the second time after February 2006.

\section{Collection of Soil Solution and Soil Samples}

Field installations for soil solution sampling, the sampling process itself, inclusive storage, transport and pre-treatment of the soil solution before the laboratory analysis were in line with the ICP IM manual (2004) for soil water chemistry [29].

Accordingly, six suction lysimeters per plot (polyvinyl chloride (PVC) pipe, $95 \times 2 \mathrm{~cm}$, connected with a $P-80$ cup, $5 \times 2 \mathrm{~cm}$, CeramTec Ag, Marktredwitz, Germany) were installed in November 2009, below the main rooting zone in $100 \mathrm{~cm}$ soil depth. After predrilling with a slightly smaller auger than the suction cups, the lysimeters were pushed directly into the soil, without applying additional active filling material. Lysimeters were evenly distributed in and between the tree rows. The soil solution was gathered in evacuated (max. 0.6 bar) 1-L glass vials, each connected via buried PVC tubing to one suction lysimeter and placed in a buried cool box next to the lysimeter field. Following the ICP manual (2004), soil solution was sampled bi-weekly to monthly. For transport and storage, solution samples were transferred into 100-ml PVC bottles and immediately stored in dark and cool conditions with a maximum temperature of $4{ }^{\circ} \mathrm{C}$. As samples should be analyzed for all major anions and cations and to avoid any analytical interference, no preservative was added prior to the analysis, which was done within the following month after field sampling. Due to relatively dry soil conditions between June and November 2010, no soil solution could be extracted during this time.

Soil samples for physical and chemical analysis were taken from one soil pit per field plot. From each horizon, three single samples were taken to determine chemical properties. On the research plots that were chosen for water balance simulations (Ref, W05/90), volume intact soil samples were taken using steel cylinders $\left(100 \mathrm{~cm}^{3}\right)$ to determine soil physical properties of the soil horizons. At W05/90, five replicate samples in soil depths of 5, 15, 25, 35, 65 and $100 \mathrm{~cm}$ were taken, to account for the heterogeneous soil profile caused by soil preparation measures. At the more homogenous profile of Ref, three replicate samples in depth 15,45 and $100 \mathrm{~cm}$ depth were taken. 
Table 1 Basic site and soil type background conditions of the research plots in the Fuhrberger Feld $(\mathrm{SR} / \mathrm{DR}=$ single/double row; $2 / 0.8 \times 0.6 \mathrm{~m}=2 \mathrm{~m}$ between, $0.8 \mathrm{~m}$ within DR; $0.6 \mathrm{~m}$ within SR)

\begin{tabular}{|c|c|c|c|c|}
\hline Plot & $\begin{array}{l}\text { Genus } \\
\text { Clone } \\
\text { Plantation spacing } \\
\text { Age (2011) }\end{array}$ & Soil treatment before planting & $\begin{array}{l}\text { Soil type, soil horizon } \\
\text { sequence, depth }(\mathrm{cm})\end{array}$ & Harvesting interventions until 2011 \\
\hline $\mathrm{P} 09 / 90$ & $\begin{array}{l}\text { Poplar } \\
\text { Mixture of clone } \operatorname{Max}^{\mathrm{a}} 1-3 \\
\text { DR }(2 / 0.8 \times 0.8 \mathrm{~m})^{\mathrm{b}} \\
2\end{array}$ & $\begin{array}{l}\text { Deep-plowing up to } 90 \mathrm{~cm} \text { soil } \\
\text { depth with a double-blade } \\
\text { plowshare (i.e., transfer of } \\
\text { the humic top layer }(30 \mathrm{~cm}) \text { to } \\
\text { a depth of } 30-60 \mathrm{~cm})\end{array}$ & $\begin{array}{l}\text { Young Treposol } \\
\text { R1 }(0-30) \\
\text { R2+E }(30-60) \\
\text { rGor }(60-80) \\
\text { rGr }(>80)\end{array}$ & 0 \\
\hline $\mathrm{P} 94 / 30$ & $\begin{array}{l}\text { Poplar } \\
\text { Row mixture of } 18 \text { clones } \\
\text { SR }(0.5 \times 2 \mathrm{~m})^{\mathrm{b}} \\
17\end{array}$ & $\begin{array}{l}\text { Conventional plowing up } \\
\text { to } 30 \mathrm{~cm} \text { soil depth }\end{array}$ & $\begin{array}{l}\text { As Ref. } \\
\text { 1Ap }(0-30) \\
\text { E }(30-40) \\
\text { Bv-rGo }(40-80) \\
\text { Cv-rGor }(>80)\end{array}$ & 2 (winter $2005+$ spring 2011) \\
\hline $\mathrm{W} 05 / 90$ & $\begin{array}{l}\text { Willow } \\
\text { Clone Tora }{ }^{\mathrm{a}} \\
\text { DR }(1.5 / 0.8 \times 0.6 \mathrm{~m})^{\mathrm{b}} \\
6\end{array}$ & as $\mathrm{P} 09 / 90$ & $\begin{array}{l}\text { Older Treposol } \\
\text { as Ref }\end{array}$ & 1 (spring 2011) \\
\hline $\mathrm{W} 94 / 30$ & $\begin{array}{l}\text { Willow } \\
\text { S. viminalis } \\
\text { DR }(1.5 / 0.9 \times 0.5 \mathrm{~m})^{\mathrm{b}} \\
17\end{array}$ & As $\mathrm{P} 94 / 30$ & As Ref & 1 (spring 2010) \\
\hline Ref & Grassland & $\begin{array}{l}\text { Abandoned cropland since the } \\
\text { early } 1990 \text { s, i.e., today covered } \\
\text { with a grass layer }\end{array}$ & $\begin{array}{l}\text { Plaggenesch-Cambisol } \\
\text { over Relictgley } \\
\text { Ah }(0-30) \\
\text { E }(30-40) \\
\text { Bv-rGo }(40-80) \\
\text { Cv-rGor }(>80)\end{array}$ & - \\
\hline
\end{tabular}

${ }^{\mathrm{a}}$ Clone Max $=$ Populus nigra $\times$ P. maximovizcii; Clone Tora $=$ Salix schwerinii $\times S$. viminalis

${ }^{\mathrm{b}}$ Fuhrberger Feld

\section{Laboratory Analysis}

The $\mathrm{pH}$ was measured on dried $\left(40{ }^{\circ} \mathrm{C},>48 \mathrm{~h}\right)$ and sieved $(\leq 2 \mathrm{~mm}$ ) soil samples using a digital $\mathrm{pH} /$ conductivity meter at a soil to water ratio of 1:2.5 (WTW GmbH Weilheim, West Germany). Total organic carbon $\left(C_{\text {org }}\right)$ and total nitrogen $\left(N_{t}\right)$ from mineral soil samples was measured from dried $\left(40{ }^{\circ} \mathrm{C}\right.$, $>48 \mathrm{~h}$ ) and grounded samples using a C-N analyzer, (CHN-ORapide, VarioEL, Elementar, Germany). Our detection limit for total $\mathrm{N}$ is $\leq 0.2 \mathrm{mg} \mathrm{g}^{-1}$ and for total $\mathrm{C} \leq 0.1 \mathrm{mg} \mathrm{g}^{-1}$. The $\mathrm{C} / \mathrm{N}$ ratio was calculated from the obtained $C_{\text {org }}$ to $N_{t}$ values.

The mineral $\mathrm{N}$ content $\left(\mathrm{N}_{\text {min }}, \mathrm{NH}_{4}{ }^{+}+\mathrm{NO}_{3}{ }^{-}\right)$was detected after extraction with $0.5 \mathrm{M} \mathrm{K}_{2} \mathrm{SO}_{4} . \mathrm{NH}_{4}{ }^{+}$and $\mathrm{NO}_{3}{ }^{-}$were determined by using continuous flow injection colorimetric (Cenco/Skalar Instruments, Breda, The Netherlands). $\mathrm{NH}_{4}{ }^{+}$ was determined using the Berthelot reaction method (Skalar Method 155-000), $\mathrm{NO}_{3}{ }^{-}$in the $\mathrm{K}_{2} \mathrm{SO}_{4}$-extract as well as in the soil solution was determined using the copper-cadmium reduction method (Skalar Method 461-00). Total dissolved nitrogen (TDN) in the $\mathrm{K}_{2} \mathrm{SO}_{4}$ extract was analyzed by the given nitrate method after $\mathrm{NH}_{4}{ }^{+}$and organic $\mathrm{N}$ compounds were converted by an alkaline persulphate and UV digestion to $\mathrm{NO}_{3}{ }^{-}$. Dissolved organic nitrogen $\left(N_{\text {org }}\right)$ was computed as: $N_{\text {org }}=\mathrm{TDN}-\left(\mathrm{NH}_{4}{ }^{+} \mathrm{N}+\mathrm{NO}_{3}{ }^{-} \mathrm{N}\right)$.

All soil water laboratory analyses were applied in line with the aforementioned ICP Manual (2004; here section 8, Data Quality Assurance and Management [29]) and soil solution nitrate analysis was cross-checked by the correlation of NO3$\mathrm{N}+\mathrm{NH} 4-\mathrm{N}$ to total $\mathrm{N}\left(R^{2}=0.985\right)$. Furthermore, quality control of our laboratory analysis are regularly applied by the integration of internal standards, replicate measurements and the contribution to external ring analysis (e.g., [30], Lab Code A56 [31] Lab No. 44).

Soil water retention characteristics were analyzed for the W05/90 and Ref using the soil cores placed on a pressure membrane apparatus. Volumetric water contents were determined at pressure heads of $\mathrm{pF} 1.0, \mathrm{pF} 1.5, \mathrm{pF} 1.8, \mathrm{pF} 2.0$, $\mathrm{pF} 2.3, \mathrm{pF} 2.5, \mathrm{pF} 3.0, \mathrm{pF} 3.3, \mathrm{pF} 3.5, \mathrm{pF} 3.7$ and $\mathrm{pF} 4.2$. 
The grain size distribution of the fine soil was determined gravimetrically after oxidization of organic carbon using $\mathrm{H}_{2} \mathrm{O}_{2}$, destruction of binding components using $\mathrm{Na}$-dithionite, following the method of Atterberg [32].

\section{Meteorological Variables}

A climate station was set up on an open field approximately $150 \mathrm{~m}$ from the W05/90 plot and $200 \mathrm{~m}$ from the Ref plot, to collect meteorological data to be used as input variables for our water balance simulations. Sensors were mounted on a $10 \mathrm{~m}$ tall mast and read out by a datalogger (D12e, Delta-T Devices). Data were collected every $5 \mathrm{~s}$, then aggregated at 10-min intervals. We measured precipitation at $1 \mathrm{~m}$ height (tipping bucket $0.1 \mathrm{~mm}$, Thies Clima, Göttingen Germany), air temperature, relative humidity (both HMP45D, Vaisala, Vantaa, Finland), global radiation (SP Lite, Kipp \& Zonen, Delft, The Netherlands) at $2 \mathrm{~m}$ height and wind speed (cup anemometer, Thies Clima) at $10 \mathrm{~m}$ height. For the use as model input, the data were checked for plausibility and later aggregated to hourly values. Data gaps in the time series due to equipment failure were filled with values from two nearby monitoring stations run by the German Weather Service. Precipitation values originate from a station about $4 \mathrm{~km}$ west of the field plots, while wind speed, relative humidity, air temperature and global radiation were taken from a station $15 \mathrm{~km}$ southwest from the field plots. Relative humidity and windspeed were adjusted to our site conditions by scaling daily mean values using linear relationships between our measurements and station data.

In 2010, precipitation was $651 \mathrm{~mm}$, with $351 \mathrm{~mm}$ falling during the growing season (May-October). The annual sum for 2011 was $662 \mathrm{~mm}$, of which $409 \mathrm{~mm}$ fell during the growing season. In 2010, a drought occurred in June and July, followed by a very wet period in August and September. The year 2011 was characterized by a cool and moist summer and a very dry and warm autumn.

\section{Measurements of Soil Water Tension and Stand Precipitation}

Soil water tensions to evaluate the simulation model performance were measured on the Ref and W05/90 plots at depths of $30 \mathrm{~cm}(n=3), 60 \mathrm{~cm}(n=3)$ and $100 \mathrm{~cm}(n=10)$, using tensiometers (ceramic: P-80, CeramTec Ag, Marktredwitz, Germany) equipped with pressure transducers (PCFA6D, Honeywell; Morristown, NJ, USA). Pressure heads at 100$\mathrm{cm}$ depth were recorded in hourly intervals from December 2009 using dataloggers (DL2 and DL2e, Delta-T Devices, Cambridge, UK). Monitoring of shallower soil depths began in May 2010. The tensiometers at 100-cm depth were placed in two parallel transects with a distance of $1 \mathrm{~m}$ between and within transects, crossing plant rows with an angle of $45^{\circ}$.
The probes were installed at an angle of $30^{\circ}$ to the soil surface in order to prevent preferential water flowing down the shaft of the instrument. Data quality assessment of water tension time series was done following the protocol described in Wegehenkel (2005) [33]. Average soil water tensions were excluded from the model performance evaluation for periods where the values of one or more tensiometers had to be rejected, i.e., because dry soil conditions beneath the measuring limit $(-850 \mathrm{hPa})$.

Stand precipitation measurements were conducted on W05/90 during the vegetation period 2010 using two $4 \mathrm{~m}$ long gutters with a width of $0.16 \mathrm{~m}\left(0.65 \mathrm{~m}^{2}\right)$ made from stainless steel. The gutters were mounted on an $80 \mathrm{~cm}$ high wooden rack, water was collected in barrels $(30 \mathrm{~L})$ that were emptied when necessary, though at minimum every second week.

\section{Vegetation Characteristics}

On the plots chosen for water balance simulations (Ref, W05/90), important vegetation characteristics like leaf area per unit ground area (leaf area index, LAI), canopy height and vertical root distributions were surveyed for the use as model input. Information on vertical root distributions came from Punzet (2011, unpublished). Canopy height was measured after the growing seasons using a measuring rod. LAI was measured with a Sunscan light interception probe (SS1, Delta-T Devices, Cambridge, UK) at three dates per growing season. As recommended by the manual of the probe, the measurements were conducted on days with stable light conditions, either on bright and sunny days or on days with a uniform overcast sky. On each measuring campaign, 50 readings were taken on fixed transect points inside the canopy. In order to avoid boundary effects, all measuring points were more than three tree lengths away from the stand edges. Before each 10 readings, the probe was referenced by measuring incident radiation outside the canopy on an open field, as well three tree lengths away from the stand edges.

\section{Statistical Analysis}

All soil properties and nitrate concentration data were checked to satisfy the conditions of normal distribution (Chi Quadrat test) homoscedasticity of residuals (Levene's test) prior parametric testing. However, critical values $(p \leq 0.05)$ indicated a non-normal distribution and unequal variances of the soil properties data set. Thus, the non-parametric Kruskal-Wallis analysis of variance approach was used to find significant $(p \leq 0.05)$ differences between chemical parameters of plots for identical soil horizons (Table 4). Statistics on soil properties were applied using the software package STATISTICA, Version 9 (StatSoftGmbH, Hamburg, Germany). 
Nitrate concentrations of the soil solution were analyzed using a linear mixed effects model [34], to account for the sample-point identity of measurements. The full model included the effect of the research plot, the drainage period (level "A": spring 2010 and level "B": winter/spring 2010/ 11 ) and their interaction effect. Sample point and sampling date were treated as random effects. Model comparisons were done using Akaike's information criterion [35] and likelihood ratio tests [34], with the conclusion that the sampling date could be excluded from random effects. Diagnostic plots were used to check normality and homoscedasticity of residuals and proved no severe violation of assumptions. For identifying differences between nitrate concentration means on the plot and drainage period level, all orthogonal contrasts were specified. The original level of significance $(\alpha=0.05)$ was adjusted to account for multiple comparisons of plots and periods. The analysis was conducted using the NLME package [36] provided by the statistical software R [37].

For evaluating the performance of the water balance simulation model, the coefficient of determination $\left(R^{2}\right)$ of a linear regression between simulated and observed values, the root mean square error (RMSE) and mean error (ME) were used as objective measures. The ME quantifies the mean absolute difference between simulated and observed values, RMSE is calculated as the square root of the mean squared difference between simulated and observed values.

\section{Simulation Model}

\section{Model Description}

The CoupModel (Version 3.0 [26]), formerly known as SOIL model, was used to estimate the components of the water balance of the Ref (grass cover) and W05/90 (willow canopy) plots. The CoupModel is a physical process model that simulates one-dimensional heat and water flows through a layered soil profile, which is covered with vegetation. It produces - after adjustment of soil and vegetation properties to site conditions - reliable estimates of evapotranspiration, groundwater recharge and other variables that are difficult to monitor in the field. In the past, it was successfully applied and verified on willow SRC stands [24, 38], crop production systems [39], forests [40, 41] and grass land sites [42]. Soil water flows are calculated by solving Richard's equation for saturated and unsaturated flow. This approach requires the hydraulic properties of the soil layers, that are described by the formulations of Brooks and Corey [43] (retention characteristics) and Mualem [44] (hydraulic conductivity). Richard's equation allows for soil water sources and sinks, i.e., root water uptake driven by transpiration. Potential transpiration $\left(T_{p}\right)$, interception evaporation $\left(E_{i}\right)$ from wet plant surfaces and soil evaporation $\left(E_{s}\right)$ are calculated separately for one or more canopy layers and the soil surface using the Penman-Monteith combination equation [45]. Actual transpiration as the sum of root water uptake from soil layers is calculated on the basis of potential transpiration, which is reduced by taking actual soil water availabilities, soil temperatures and root densities of the soil layers into account.

\section{Simulation Setup and Parameterization}

The simulations of the Ref and W05/90 plots were run with hourly resolution from January 2009 (initial soil water tension of all layers, $-60 \mathrm{hPa}$ ) until the end of December 2011, driven by the meteorological input data set. The period of interest includes the years 2010 and 2011, for which daily output of water balance components and state variables were produced. For both simulations, soil profiles with 20 layers and a total depth of $2.55 \mathrm{~m}$ were defined. The thickness of the soil layers gradually increased from $5 \mathrm{~cm}$ in the uppermost $35 \mathrm{~cm}$ to $30 \mathrm{~cm}$ in the two deepest layers. Upper and lower boundary conditions were defined as flux boundaries with the upper boundary taking the stand precipitation into account. As lower boundary condition, a unit gradient gravitational water flow was setup, which in this study represents groundwater recharge. Capillary rise was not considered.

For the description of the physical and physiological properties of the willow canopy (i.e., stomata and aerodynamic resistance functions according to [46, 47]), we used the parameterisation of Persson and Lindroth [38] (Table 3). They simulated evapotranspiration rates of a willow stand on clay soil using the older version (SOIL) of the CoupModel and verified the model with measured stand evapotranspiration. $R^{2}$ ranged from 0.73 to 0.79 , the model only slightly overestimated evapotranspiration during two growing seasons by 2 and $10 \mathrm{~mm}$ [38].

Vegetation (Table 3) and soil characteristics (Table 2) were chosen to represent our site conditions with respect to measured LAI, canopy height, root distribution and soil hydraulic properties. Model LAI development during the growing seasons was defined to match the measured values on W05/90. For estimating the actual dates of budburst and leaf fall, we applied a critical day length and temperature sum model [26]. A maximum stand average LAI of $4.2 \mathrm{~m}^{2} \mathrm{~m}^{-2}$ was reached in June 2010. In the following month, LAI dropped to about $2 \mathrm{~m}^{2} \mathrm{~m}^{-2}$, likely due to enduring water scarcity. In 2010, average canopy height of the willow stand was $7.5 \mathrm{~m}$. After harvest in early 2011, the stand re-sprouted to about $3 \mathrm{~m}$ during the growing season. The maximum LAI $\left(3.8 \mathrm{~m}^{2} \mathrm{~m}^{-2}\right)$ of the growing season 2011 was reached at the end of August.

The observed root distribution was in good accordance to other reported observations [48] in SRC stands. Most fine roots $(80 \%)$ were found in the upper $60 \mathrm{~cm}$ of the soil 
Table 2 Soil hydraulic properties used in the water balance simulation for the plots Ref and W05/90

\begin{tabular}{|c|c|c|c|c|c|c|c|c|c|}
\hline Plot & Depth $(\mathrm{cm})$ & $\begin{array}{l}\text { Lambda } \\
(-)\end{array}$ & $\begin{array}{l}\text { Air entry } \\
(\mathrm{hPa})\end{array}$ & $\begin{array}{l}\text { Saturation } \\
\text { (vol\%) }\end{array}$ & $\begin{array}{l}\text { Wilting point } \\
\text { (vol. \%) }\end{array}$ & $\begin{array}{l}\text { Residual water } \\
\text { (vol\%) }\end{array}$ & $\begin{array}{l}\text { Matrix cond. } \\
\left(\mathrm{mm} \mathrm{day}^{-1}\right)\end{array}$ & $\begin{array}{l}\text { Total cond. } \\
\left(\mathrm{mm} \text { day }^{-1}\right)\end{array}$ & Tortuosity (-) \\
\hline \multirow[t]{3}{*}{ Ref } & $0-35$ & 0.196 & 5.02 & 52.0 & 10.3 & 4.2 & 2,000 & 2,000 & 1 \\
\hline & $35-55$ & 0.478 & 1.84 & 44.1 & 6.3 & 2.0 & 5,000 & 5,000 & 1 \\
\hline & $55-255$ & 0.816 & 0.82 & 38.8 & 3.8 & 6.7 & 10,000 & 10,000 & 1 \\
\hline \multirow[t]{6}{*}{$\mathrm{W} 05 / 90$} & $0-10$ & 0.464 & 1.98 & 46.4 & 3.6 & 6.9 & 1,070 & 1,070 & 1 \\
\hline & $10-20$ & 0.204 & 7.75 & 55.6 & 9.5 & 6.6 & 8,100 & 8,100 & 1 \\
\hline & $20-35$ & 0.246 & 8.36 & 55.4 & 10.9 & 17.2 & 5,400 & 5,400 & 1 \\
\hline & $35-55$ & 0.118 & 1.71 & 51.0 & 9.9 & 3.9 & 740 & 740 & 1 \\
\hline & $55-70$ & 0.518 & 1.91 & 48.9 & 6.3 & 13.3 & 2,350 & 2,350 & 1 \\
\hline & $70-255$ & 0.816 & 5.62 & 38.8 & 3.8 & 6.7 & 10,800 & 10,800 & 1 \\
\hline
\end{tabular}

profile. Below the $\mathrm{R} 2+\mathrm{E}$ horizon, roots sporadically occurred down to a depth of $180 \mathrm{~cm}$.

The parameters of the retention function (Table 2) were obtained by least squares fitting of observed water content/ pressure head points of the horizons. Hydraulic conductivity functions were derived from the grain size distributions using built-in CoupModel routines. In spring 2011, soil water tensions in $30 \mathrm{~cm}$ indicated root water uptake, before the recently harvested willow stand had developed new shoots. To account for this water uptake, a grass layer was defined underneath the willow canopy. This grass layer was assumed to have the same properties as the grass layer defined in the simulation of the Ref plot (Table 3), except for the maximum LAI, which we assigned a lower value $\left(3 \mathrm{~m}^{2} \mathrm{~m}^{-2}\right)$. Vegetation properties to simulate the Ref plot were taken from Lundmark [42], hydraulic properties of the soil horizons and the vertical root distribution were derived from field measurements. On the Ref plot, most fine roots (95\%) were located in the former Ap horizon, only few roots of dicot plants reached down to $90 \mathrm{~cm}$.

With respect to our measured stand precipitation and soil water tension data, adjustments of the original parameter sets $[38,42]$ had to be carried out, to obtain a better agreement between simulated and measured variables and thus a better estimation of the water balance components. Stand precipitation measurements on the willow plot indicated underestimated interception evaporation when using the canopy storage capacity parameters $\left(I_{\mathrm{c}}, I_{\mathrm{LAI}}\right)$ of a previous study [38], likely due to the higher temporal resolution $(1 \mathrm{~h})$ of our simulation. Adjustments of these parameters and the interception surface resistance ( $r_{\text {ci }}$, Table 3$)$ led to a better agreement between simulated and observed stand precipitation. Hydraulic conductivities derived from grain size distributions were adjusted considering the observed soil water tensions at field capacity during winter time. The RWU parameter for water uptake compensation was used to improve the agreement between observed and simulated soil water tensions during the growing season.
Table 3 Adjusted CoupModel parameter values for the simulations of the W05/90 and Ref plots

\begin{tabular}{|c|c|c|c|}
\hline CoupModel parameter & Unit & $\begin{array}{l}\text { Willow canopy } \\
\text { W05/90 }\end{array}$ & $\begin{array}{l}\text { Grass layer } \\
\text { Ref }\end{array}$ \\
\hline $\begin{array}{l}\text { Interception constant } \\
\text { capacity }\left(I_{c}\right)\end{array}$ & $\mathrm{mm}$ & 0.2 & 0 \\
\hline $\begin{array}{l}\text { Interception capacity } \\
\text { per LAI }\left(I_{L A I}\right)\end{array}$ & $\mathrm{mm}$ & 0.25 & 0.25 \\
\hline $\begin{array}{l}\text { Interception surface } \\
\text { resistance }\left(r_{c i}\right)\end{array}$ & $\mathrm{s} \mathrm{m}^{-1}$ & 0.5 & 5 \\
\hline Reference height & $\mathrm{m}$ & 10 & 2 \\
\hline $\begin{array}{l}\text { Parameter in soil } \\
\text { surface resistance } \\
\text { function }\end{array}$ & $\mathrm{hPa}$ & 1,000 & 1,000 \\
\hline $\begin{array}{l}\text { Crit. threshold for } \\
\text { water uptake } \\
\text { reduction }\left(\Psi_{\text {crit }}\right)\end{array}$ & $\mathrm{hPa}$ & 400 & 400 \\
\hline $\begin{array}{l}\text { Degree of root water } \\
\text { uptake compensation } \\
\text { from moist soil } \\
\text { layers (RWU } \text { comp })\end{array}$ & - & 0.45 & 0.25 \\
\hline $\begin{array}{l}\text { Maximum stomata } \\
\text { conductance }\left(g_{\max }\right)\end{array}$ & $\mathrm{m} \mathrm{s}^{-1}$ & 0.015 & 0.02 \\
\hline $\begin{array}{l}\text { Sensitivity of stomata } \\
\text { conductance to } \\
\text { VPD }(b)\end{array}$ & $\mathrm{Pa}$ & 1,318 & 100 \\
\hline $\begin{array}{l}\text { Sensitivity of stomata } \\
\text { conductance to } \\
\text { global short wave } \\
\text { radiation }\left(R_{0}\right)\end{array}$ & $\mathrm{MJ} \mathrm{m}^{-2}$ day $^{-1}$ & 11.8 & 5 \\
\hline $\begin{array}{l}\text { Aerodynamic } \\
\text { resistance }\left(r_{a}\right)\end{array}$ & $\mathrm{s} \mathrm{m}^{-1}$ & $3-676$ & $30-708$ \\
\hline Root depth & $\mathrm{m}$ & 1.8 & $0.7-1.0$ \\
\hline Canopy height & $\mathrm{m}$ & $0.1-7.5$ & $0.05-0.35$ \\
\hline Leaf area index (LAI) & $\mathrm{m}^{2} \mathrm{~m}^{-2}$ & $0-4.2$ & $1.5-3.5$ \\
\hline $\begin{array}{l}\text { Critical air temperature } \\
\text { for temperature sum } \\
\text { calculation }\end{array}$ & ${ }^{\circ} \mathrm{C}$ & 9 & 8.5 \\
\hline $\begin{array}{l}\text { Temperature sum to } \\
\text { start leaf } \\
\text { development }\end{array}$ & ${ }^{\circ} \mathrm{C}$ & 50 & 50 \\
\hline
\end{tabular}


As in the simulation of W05/90 plot, adjustments of the Ref parameter set included soil hydraulic conductivities and root water uptake compensation ( $\mathrm{RWU}_{\text {comp }}$ ). Additionally, the shape of the seasonal LAI development was adjusted.

\section{Results}

\section{Basic Soil Parameters}

The $C_{\text {org }}$ and the $N_{t}$ of the soil profiles clearly mirror the deep-plowing effect on the plots P09/90 and W05/90 (Table 4). $C_{\text {org }}$ and $N_{t}$ values are enhanced in the mid soil layers of 30-50 cm soil depth, whereas highest $C_{\text {org }}$ and $N_{t}$ values of the reference plot (Ref) and the two conventionally plowed (30 cm soil depth) poplar and willow plots (P94/30, W94/30) were found in the upper $0-30 \mathrm{~cm}$ soil depth. With more than $7 \%, C_{\text {org }}$ content was highest in the upper $10 \mathrm{~cm}$ of the reference plot and lowest in the top layer of the deeply plowed P09/90 plot $\left(0.2 \% C_{\text {org }}\right)$. Due to the soil mixture after the plowing on the SRC plots, measured soil values generally indicate a high spatial variability and thus could only be proved to be statistically different in some cases (e.g., for $C_{\text {org }}$ and $N_{t}, \mathrm{P} 09 / 90$ versus Ref., $0-10 \mathrm{~cm}$ soil depth). Because of relatively low $C_{\text {org }}$ values in the top and lowest layer of the $\mathrm{P} 09 / 90$ plot, $\mathrm{C} / \mathrm{N}$ ratios are relatively low as well (9.9-10.9).
On the other plots, $\mathrm{C} / \mathrm{N}$ ratios ranged from about 11 in the lower soil horizons (Ref, $30-50 \mathrm{~cm}$ soil depth) to more than 26 in the upper soil horizons (P94/30). Even if not statistically provable, there is a tendency towards relatively low $\mathrm{C} / \mathrm{N}$ ratios for all soil layers on the deeply plowed P09/90 and W05/90 plots, which might already indicate the potential of nitrate leaching on these two plots. Results of the mineral $\mathrm{N}$ analysis $\left(\mathrm{N}_{\text {min }}\right)$ indicate a shift towards higher values only in the 10$30 \mathrm{~cm}$ soil layer in the P09/90 and W05/90 plots, while horizons below and above showed reduced values. Conventional plowing of the topsoil $(30 \mathrm{~cm})$ alone, as applied at the $\mathrm{P} 94 / 30$ and W94/30 plots did not change the vertical gradient of the $\mathrm{N}_{\min }$ values, compared to the reference plot.

Compared to conventional cropland sites of the region $\mathrm{N}_{\min }$ values are low. Higher $\mathrm{N}_{\min }$ values of the top soilrespectively the former top soil in 10-30 cm soil depth on the plowed $\mathrm{P} 09 / 90$ and W05/90 plots - are correlating with higher values of $N_{\text {org. }}$. Furthermore, mean percentage of nitrate in total $\mathrm{N}_{\text {min }}\left(\mathrm{NO}_{3}+\mathrm{NH}_{4}\right)$ was not detectable in the $30-50 \mathrm{~cm}$ soil layer at the reference plot but also not in the most upper layer of the P09/90 plot - which in fact here is also the former deep layer, transferred by deep plowing to the top of the profile. As far as $\mathrm{N}_{\min }$ was detectable in deeper horizons at all SRC plots, nitrate was the dominant constituent. The $\mathrm{pH}(1 \mathrm{M} \mathrm{KCl})$ values of all plots and soil layers range between 4.1 and 5.7, with a tendency towards higher

Table 4 Mean $( \pm \mathrm{SD})$ soil chemical background conditions of the SRC plots in the Fuhrberger Feld

\begin{tabular}{|c|c|c|c|c|c|c|c|c|}
\hline Plot & Soil depth (cm) & $\mathrm{pH}(1 \mathrm{M} \mathrm{KCl})$ & $C_{\text {org }}(\mathrm{mg} / \mathrm{g})$ & $N_{t}(\mathrm{mg} / \mathrm{g})$ & $\mathrm{C} / \mathrm{N}(\mathrm{mg} / \mathrm{mg})$ & $\mathrm{N}_{\min }\left(\mathrm{NO}_{3}+\mathrm{NH}_{4}\right)(\mathrm{mg} / \mathrm{kg})$ & $\mathrm{NO}_{3} / \mathrm{N}_{\min }(\%)$ & $N_{\text {org }}(\mathrm{mg} / \mathrm{kg})$ \\
\hline \multirow[t]{4}{*}{$\mathrm{P} 09 / 90$} & $0-10$ & $4.4(0.2)$ & $2.0(0.2) a$ & $0.2(0.0) a$ & $9.9 a$ & $\leq$ d.l. & 0 & $2.57(0.81) a$ \\
\hline & $10-30$ & $5.0(0.4)$ & $13.0(10.4)$ & $0.8(0.6)$ & $14.3 a$ & $7.29(1.09)$ & 79 & $6.98(0.87)$ \\
\hline & $30-50$ & $5.1(0.2)$ & $40.7(3.2)$ & $2.4(0.1)$ & 16.8 & $1.62(0.00)$ & 100 & $2.33(1.08)$ \\
\hline & $50-70$ & $4.1(0.2)$ & $2.3(1.5)$ & $\leq \mathrm{d} .1$ & - & n.t. & - & n.t. \\
\hline \multirow[t]{4}{*}{$\mathrm{P} 94 / 30$} & $0-10$ & $4.6(0.1)$ & $52.8(1.9)$ & $2.0(0.1)$ & $26.4 b$ & $2.86(0.86)$ & 74 & $5.56(0.48)$ \\
\hline & $10-30$ & $4.6(0.1)$ & $50.5(3.0)$ & $1.8(0.1)$ & $27.6 b$ & $1.62(0.00)$ & 100 & $6.78(0.68)$ \\
\hline & $30-50$ & $4.4(0.1)$ & $10.9(4.1)$ & $0.5(0.2)$ & $22.0 a$ & $\leq \mathrm{d} .1$ & 0 & $2.69(0.23)$ \\
\hline & $50-70$ & $4.3(0.1)$ & $4.8(2.2)$ & $0.3(0.1)$ & 18.6 & n.t. & - & n.t. \\
\hline \multirow[t]{4}{*}{$\mathrm{W} 05 / 90$} & $0-10$ & $5.2(0.2)$ & $19.1(8.4)$ & $1.1(0.5)$ & 17.2 & $1.17(0.00)$ & 100 & $3.73(1.14)$ \\
\hline & $10-30$ & $5.7(0.3)$ & $44.7(2.3)$ & $2.6(0.1)$ & 17.5 & $3.67(0.69)$ & 84 & $7.21(1.19)$ \\
\hline & $30-50$ & $5.7(0.2) a$ & $42.8(8.2) a$ & $2.5(0.5) a$ & 17.3 & $0.66(0.00)$ & 100 & $2.78(0.66)$ \\
\hline & $50-70$ & $4.1(0.2)$ & $2.4(0.4)$ & $\leq \mathrm{d} .1$ & - & n.t. & - & n.t. \\
\hline \multirow[t]{4}{*}{$\mathrm{W} 94 / 30$} & $0-10$ & $5.2(0.2)$ & $53.2(3.2)$ & $2.2(0.1)$ & 24.0 & $2.83(0.86) b$ & 74 & $5.56(1.00)$ \\
\hline & $10-30$ & $4.9(0.1)$ & $47.7(4.9)$ & $1.9(0.1)$ & 25.1 & $1.52(0.00)$ & 100 & $6.78(0.58)$ \\
\hline & $30-50$ & $4.6(0.3)$ & $30.6(12.9)$ & $1.3(0.2)$ & 24.3 & $0.29(0.00)$ & 100 & $2.69(0.70)$ \\
\hline & $50-70$ & $4.2(0.2)$ & $5.6(1.9)$ & $0.3(0.1)$ & 19.4 & n.t. & - & n.t. \\
\hline \multirow[t]{4}{*}{ Ref } & $0-10$ & $4.4(0.1)$ & $71.7(12.6) b$ & $3.2(0.6) b$ & 22.6 & $2.40(0.70)$ & 75 & $6.72(0.91) b$ \\
\hline & $10-30$ & $4.5(0.5)$ & $59.3(31.3)$ & $2.4(1.1)$ & 24.3 & $1.76(0.67)$ & 67 & $5.47(1.14)$ \\
\hline & $30-50$ & $4.3(0.1) b$ & $1.9(0.3) b$ & $0.2(0.0) b$ & $11.4 b$ & $\leq \mathrm{d} .1$ & 0 & $2.24(2.12)$ \\
\hline & $50-70$ & $4.2(0.1)$ & $2.1(1.1)$ & $\leq \mathrm{d} .1$ & - & n.t. & - & n.t. \\
\hline
\end{tabular}

Samples were taken in June 2010 with $n=3$ per layer and plot (d.l. detection limit, $n$.t. not detected). Different letters indicate significant $(p \leq 0.05)$ differences between the same soil layer of different plots 
values on the W05/90 plot. However, differences proved to be statistically significant in only one case $(30-50 \mathrm{~cm}$ soil depth, W05/90 versus Ref).

\section{Nitrate Soil Solution Concentrations}

Figure 1 shows the time series of monthly mean nitrate concentrations in the soil solution at $100 \mathrm{~cm}$ soil depth, measured from February to May 2010 (period A) and from December 2010 to June 2011 (period B). Estimated nitrate concentration means including standard errors as well as statistical differences between means of the plots and between periods are given in Table 5. Statistical tests show that plot and period both have a significant influence $(p<0.0001)$ on nitrate concentrations. The significant $(p<0.0001)$ interaction between both factors suggests different plot behavior for the sampling periods.

In period A (spring 2010), there is a relatively clear sequence of the nitrate concentration levels between a mean of above 16 to below $1 \mathrm{mg} \mathrm{NO}_{3}-\mathrm{N} \mathrm{L}^{-1}\left(\mathrm{P} 09 /{ }_{90}>\mathrm{W} 94 /{ }_{30}>\mathrm{W} 05 / 90>\mathrm{P} 94 /{ }_{30}>\right.$ Ref, Fig. 1). Concentrations of Ref and P94/30 thereby do not differ significantly from zero (Table 5a). In period B (winter/ spring 2010/11; Table 5b), only the concentrations of W94/30 remain on the same high level of period A (no significant differences between periods). Nitrate concentrations of P94/30 in period $\mathrm{B}$ are as well at the very low concentration level of the reference plot, concentrations of $\mathrm{P} 09 / 90$ and W94/30 remain significantly higher than concentrations of Ref (Table 5). At the beginning of period $\mathrm{B}$, nitrate concentrations of P09/90 started again at an elevated level but then strongly decreased to the level of the W05/90 plot. Finally, the estimated mean nitrate concentration of $\mathrm{W} 05 / 90$ in period B turned out to be significantly reduced compared to period A (Table $5 \mathrm{a}, \mathrm{b}$ ).

Significant differences of the estimated mean nitrate concentrations in period A were found for the comparisons
Ref-P09/90, Ref-W94/30, P09/90-P94/30, and P09/90-W05/90 (Table 5a). In period B (Table 5b), the differences between W05/90 and P09/90 were not significant anymore, but the differences between W94/30 and P94/30 became significant.

However, as already described for the soil matrix, the spatial variability of the solute nitrate concentrations is high, especially when the concentration is low. In both sampling periods, the variation coefficient is between 100 and $200 \%$ on the P94/30 plot, but is lower (around 14-65\%) when nitrate concentrations are enhanced (P09/90 and W94/30, both periods).

\section{Simulated and Observed Pressure Heads}

Figure $2 \mathrm{a}$ and $\mathrm{b}$ show the time series of the mean, minimum and maximum observed soil water tensions in $100 \mathrm{~cm}$ depth on the Ref and W05/90 plots, in combination with the corresponding simulated values of the soil layer in $95-105 \mathrm{~cm}$ depth. The seasonal pattern is similar on both plots. During winter, all tensiometers show values around field capacity. With budburst in spring and beginning root water uptake, soil water potentials start to decrease and the spatial variability increases. Pressure heads on Ref start to decrease later, less strong and in fewer locations compared to the pressure heads of the willow plot. As a consequence, thorough rewetting of the soil on Ref is attained earlier in autumn when root water uptake ceases. In 2010, drainage formation on Ref can be expected to start already after a heavy rain storm at the end of August after which soil water potentials in $100 \mathrm{~cm}$ indicate field capacity. At the same time, many tensiometers on the W05/90 plot did not work properly, indicating soil water tensions near or beyond the measuring limit (-850 hPa) since July 2010.

A similar seasonal pattern is revealed by tensiometry in summer 2011. After a series of heavy rain storms at the end of June, the soil in $100 \mathrm{~cm}$ depth on Ref is completely
Fig. 1 Monthly mean nitrate concentrations of SRC plots in the Fuhrberger Feld at $100 \mathrm{~cm}$ soil depth from Feb 2010 to Jun 2011 (due to dry conditions, no samples could be obtained between June and Nov 2011)

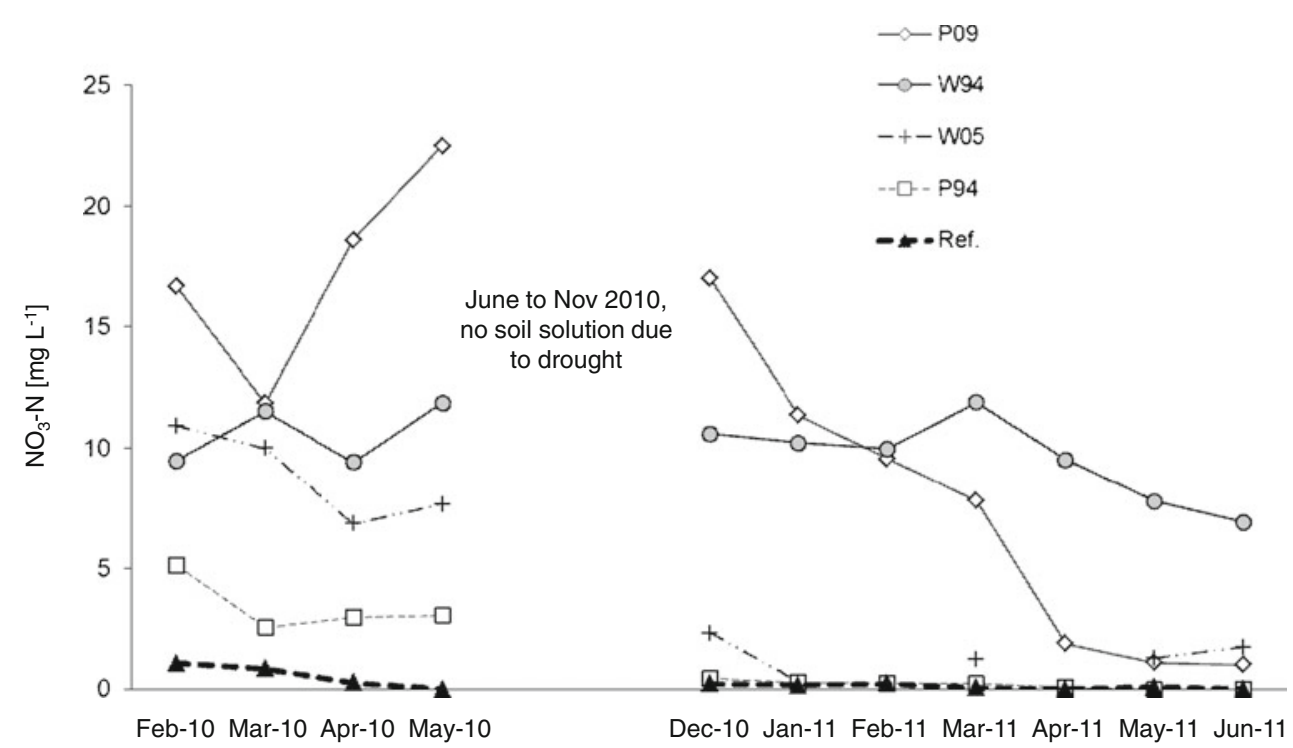


Table 5 Estimated mean nitrate concentrations $\left(\mathrm{NO}_{3}-\mathrm{N} \mathrm{L}^{-1}\right)$ of the study plots, separated for period A (Feb 2010-May 2010; Table 5a) and period $\mathrm{B}$ (Dec 2010-June 2011; Table 5b)
On the diagonal: estimates, intercept significance levels (n. sign. not significant) and standard errors (SE) of estimates. Letters denote significant membership to the periods A and B. Significances for plot comparisons are specified below the diagonal. The original significance level $\alpha=0.05$ was adjusted to account for multiple comparisons

\begin{tabular}{|c|c|c|c|c|c|}
\hline $\begin{array}{l}\text { Estimate } \\
p \text { value } \\
\mathrm{SE}\end{array}$ & Ref & $\mathrm{P} 09 / 90$ & $\mathrm{P} 94 / 30$ & W05/90 & $\mathrm{W} 94 / 30$ \\
\hline
\end{tabular}

a) Ref $\quad 0.62 \mathrm{~A}, \mathrm{~B}$

n. sign.

1.77

$\mathrm{P} 09 / 90<0.0001 \quad 16.64 \mathrm{~A}$

$<0.0001$

1.61

$\mathrm{P} 94 / 30$

n. sign.

$<0.0001$

$3.33 \mathrm{~A}, \mathrm{~B}$

n.sign.

1.63

W05/90 n.sign. $<0.0001 \quad$ n. sign.

$7.81 \mathrm{~A}$

$<0.0001$

1.64

$\mathrm{W} 94 / 30$

0.0007

n.sign.

n.sign,

n. sign.

$10.38 \mathrm{~A}, \mathrm{~B}$ $<0.0001$

b)

Ref

$0.11 \mathrm{~A}, \mathrm{~B}$

n. sign.

1.59

$\mathrm{P} 09 / 90$

0.0005

$9.1 \mathrm{~B}$

$<0.0001$

1.57

P94/30

n.sign.

0.0005

$0.27 \mathrm{~A}, \mathrm{~B}$

n. sign.

1.53

W05/90

n. sign.

n. sign.

n. sign.

$2.23 \mathrm{~B}$

n. sign.

1.75

W94/30

0.0002

n. sign.

0.0002
$10.09 \mathrm{~A}, \mathrm{~B}$ $<0.0001$ rewetted and remains relatively moist throughout the rest of the growing season. Potentials on W05/90 show only slight increases during that period. The soil stays relatively dry, though inside the measuring range until beginning of December 2011. Thus, considerable groundwater recharge cannot be expected before the end of the year.

The visible agreement between observed and simulated soil water tensions, in combination with performance indicators (Table 6) suggests an acceptable performance of the CoupModel. The important points in time like the beginning of root water uptake in spring and the rewetting in autumn meet well with observations, except for the rewetting in autumn 2010 on W05/90. Here, the point in time of water flow breakthrough in $100 \mathrm{~cm}$ could not be monitored, due to measuring errors caused by the dry subsoil. However, coefficients of determination (Table 6) are relatively good for pressure head data [33] and the absolute deviation from measurements is low. The fact that measured values of soil water storage capacities (retention curves) were used in the simulations and throughfall was only slightly overestimated (ME; $1.4 \mathrm{~mm}$, Table 6 , possibly due to wetting and evaporation losses during measurements), strengthens our belief that the estimations of the water balance components are reliable.

\section{Simulated Water Budgets}

The monthly and annual sums of the simulated water balance components for the study plots are illustrated in Fig. 3a 

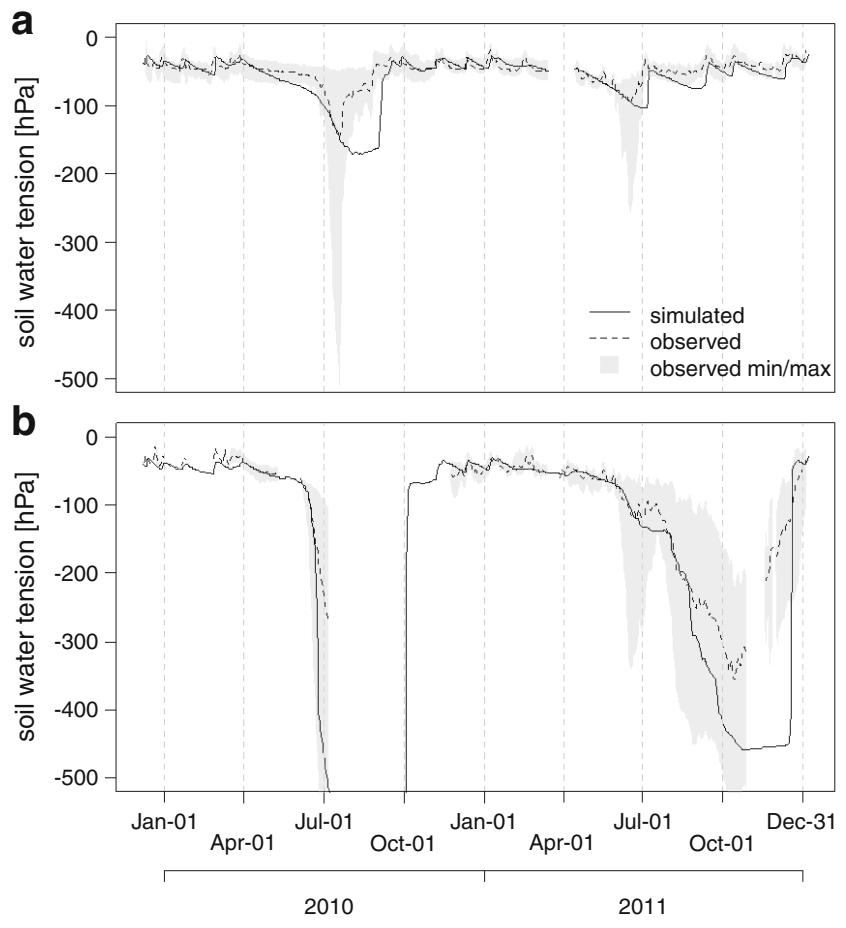

Fig. 2 a, b Mean observed $(n=10)$ and simulated soil water tensions of Ref (a) and W05/90 (b) study plots at $100 \mathrm{~cm}$ soil depths. Shaded area $\operatorname{minimum} /$ maximum of observations

and $b$ and Table 7. Interception and transpiration of the willow plot include the evaporation rates of the grass layer beneath the willow canopy.

Similar to the seasonal variation in the soil water tensions, a clear pattern can be seen in the monthly sums of the water balance components of the study plots. Actual evapotranspiration $\left(\mathrm{ET}_{\mathrm{a}}\right)$ as the sum of transpiration $\left(T_{a}\right), E_{i}$ and $E_{s}$ has the highest values during the growing season, whereas drainage from the soil profiles takes place mainly in winter. The transitions between these hydrological seasons are smooth, with a gradual shift towards $\mathrm{ET}_{\mathrm{a}}$ in spring and a more abrupt beginning of the drainage period in autumn or winter. Simulated monthly $E_{i}$ and $T_{a}$ from W05/90 are higher than from Ref (Fig. 3a); in summer, $\mathrm{ET}_{\mathrm{a}}$ generally is equal or even higher than precipitation. In July $2010, T_{a}$ is extraordinary low in both simulations, due to low amounts of precipitation in June and July and pronounced soil water deficits in the root zone.

The simulated groundwater recharge from W05/90 ceases during summer almost completely, while small amounts of drainage are formed on Ref throughout the whole observation period. On Ref, considerable monthly groundwater recharge rates are attained already in October 2010, while groundwater recharge from W05/90 does not start before December. In 2011, the winter drainage period did not start until the end of the simulation period, whereas seepage from Ref started to increase already in October.

The differences in seasonal water partitioning patterns between the simulated land use types are reflected in the annual sums of the water balance components. Especially annual $E_{i}$ and $T_{a}$ are higher from the willow stand (Table 7). During the simulation period, average $E_{i}$ losses from W05/90 account for $25 \%$ of precipitation, contrasted by $12 \%$ on Ref. Simulated root water uptake on W05/90 is in both years about $60 \mathrm{~mm}$ higher.

The differences in annual evapotranspiration rates between the land use types result in large differences in the amount of water leaving the soil profiles and serving as groundwater recharge. On Ref, $345 \mathrm{~mm}$ drainage formed in the year 2010 (Table 7), which is more than half of the annual precipitation. In contrast to that, $189 \mathrm{~mm}(29 \%$ of precipitation) groundwater recharge is formed on W05/90. In 2011, these differences are not as expressed, although the soil profile of W05/90 was not rewetted completely (Table 7) by the end of the simulation period. For the whole simulation period, average annual groundwater recharge from W05/90 $\left(180 \mathrm{~mm} \mathrm{a}^{-1}\right)$ is approximately $40 \%$ lower than groundwater recharge from Ref $\left(300 \mathrm{~mm} \mathrm{a}^{-1}\right)$.

\section{Discussion}

The German Biomass Research Center [49] has calculated that by 2020 , there will be a net lack of about 270 PJ per year in the German energy and material related wood market. If this "wood gap" would be filled by the establishment of SRC plantations, it would result in an extra need of about 1.2 million ha [49]. The current (2011) total cropland area in
Table 6 Performance statistics for simulated soil water tensions and throughfall. Indicators for soil water tension performance are means for three $(30-35 \mathrm{~cm}$; $55-65 \mathrm{~cm})$ respectively ten $(95-105 \mathrm{~cm})$ tensiometers

\begin{tabular}{lllllll}
\hline Variable & Plot & Horizon $(\mathrm{cm})$ & $R^{2}$ & RMSE & ME & $n$ Obs. \\
\hline Soil water tension & \multirow{2}{*}{ Ref } & $30-35$ & 0.67 & $148 \mathrm{hpa}$ & $-81 \mathrm{hpa}$ & 512 \\
& & $55-65$ & 0.52 & $177 \mathrm{hpa}$ & $-71 \mathrm{hpa}$ & 606 \\
& & $95-105$ & 0.49 & $26 \mathrm{hpa}$ & $-10 \mathrm{hpa}$ & 761 \\
& $\mathrm{~W} 05 / 90$ & $30-35$ & 0.61 & $299 \mathrm{hpa}$ & $-101 \mathrm{hpa}$ & 582 \\
& & $55-65$ & 0.55 & $218 \mathrm{hpa}$ & $-5 \mathrm{hpa}$ & 582 \\
Throughfall & W05/90 & - & 0.68 & $185 \mathrm{hpa}$ & $-83 \mathrm{hpa}$ & 685 \\
\hline
\end{tabular}




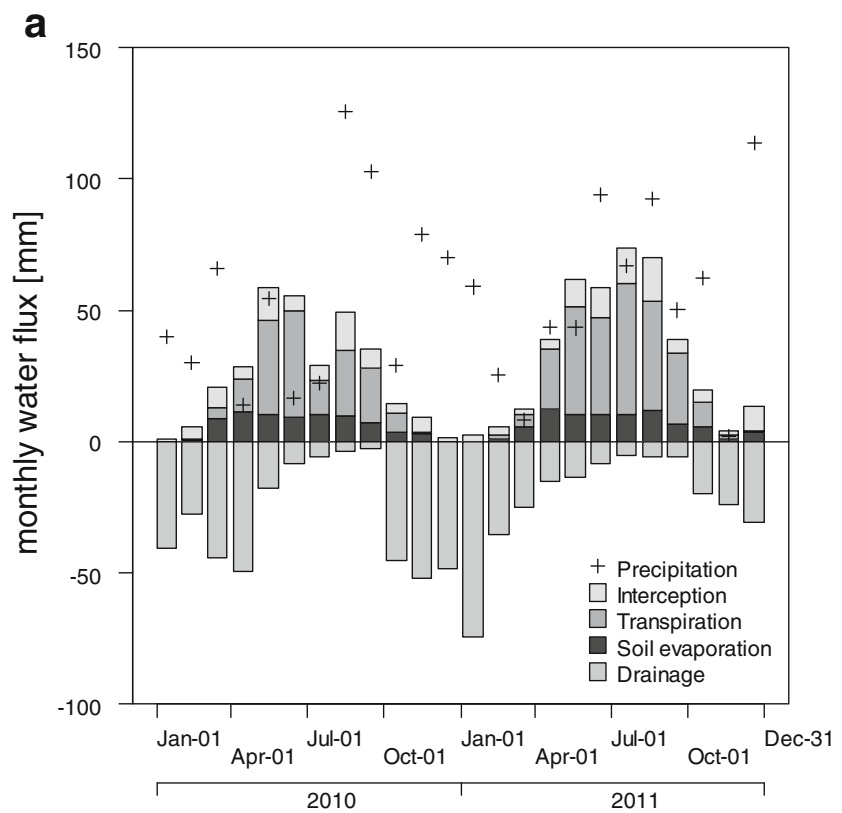

b

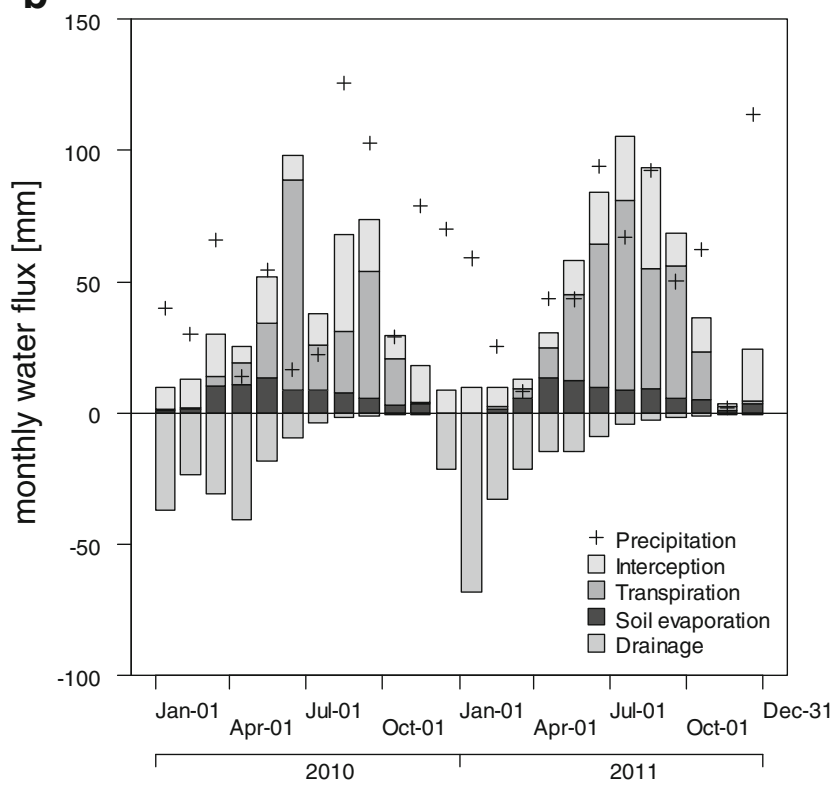

Fig. 3 a, b Simulated monthly water fluxes for Ref (a) and $\mathrm{W} 05 / 90$ (b). Groundwater recharge (drainage) is presented by negative values

Germany is about 12 million ha, where approximately 2.3 million ha is used for bioenergy raw material production [5]. As of today, SRC contribute to only approximately 5,000 ha [50], it may be unrealistic to fill the forecasted wood gap in Germany by using only SRC.

Thus, and in accordance with Fritsche et al. [51], the cultivation of bioenergy crops on natural or semi-natural land that is currently not under specific production, is expected to increase. However, in comparison with conventional crops for bioenergy production (e.g., canola, maize), SRC may even increase ecological services on the field as well as on the landscape level [52-56]. SRC may act as physical barriers in the formation of "arable deserts" and protect against soil erosion or act as riparian or groundwater buffer strips to protect soil and water qualities in the context of the Water Framework Directive 2006/118/EU [57].

Furthermore, the cultivation of biomass on unused degraded land or on abandoned farmland as applied in this study can be seen as a safeguard against negative indirect land use change effects, as described by Fritsche et al. [51].

In the given study, the general focus of the implemented $\mathrm{SRC}$ is to protect drinking water resources from nitrate pollution while simultaneously producing biomass feedstock on an extensive level, i.e., without any further input of $\mathrm{N}$ fertilizers or other chemicals. However, as drinking water is the most important product of land use, groundwater recharge rates have to be considered as well.

According to Gadgil et al. [58], the Fuhrberg recharge zone can thus be described as an "ecologically sensitive area" which is both, ecologically and economically important, but, vulnerable to even mild disturbances and hence demands careful management. In Fuhrberger Feld, reduced nitrate loads were achieved by setting aside arable cropland as demonstrated by the low nitrate leaching measured from the reference plot (Fig. 1).

Nevertheless, is it not clear how sustainable this approach is in the long-run. The $\mathrm{C}$ - and N-rich topsoil horizon is a potential source of nitrate leaching coming from mineralization pulses and accordingly may be vulnerable to any disturbances such as droughts, subsequent rewetting or even fire, all of which lead to a release of organically bound $\mathrm{N}$ sources. Such a disturbance effect can be followed on plot P09/90, where the site preparation measures (deep plowing) were followed by a distinct nitrate pulse in period A (FebMay 2010). Enhanced amounts of organically bound N sources were made available and subsequently leached as nitrate to the groundwater.

However, nitrate leaching may also exhibit a high temporal variability, as evident from plot W05/90. Here, nitrate concentrations were in the range of the drinking water threshold value of $11.3 \mathrm{mg} \mathrm{NO}-\mathrm{N} \mathrm{L}^{-1}$ (i.e., $50 \mathrm{mg} \mathrm{NO3}{ }^{-} \mathrm{L}^{-1}$ [27]) during period A, but significantly decreased to the very low level of the reference plot in period B (Dec 2010 to Jun 2011). The same trend was evident for $\mathrm{P} 94 / 30$, though the starting nitrate concentrations were less pronounced (mean in period A, $3.3 \mathrm{~m} \mathrm{~L}^{-1}$ ) but also exhibited considerable variability around the mean $( \pm 3.4 \mathrm{SD})$. As the nitrate concentrations in P94/30 were always clearly below the drinking water threshold, it can be concluded that SRC, at least in the long term, do not leach critical amounts of nitrate.

As indicated in Table 4, higher $\mathrm{C}$ and $\mathrm{N}$ contents as well as higher $\mathrm{C} / \mathrm{N}$ ratios are present in the deeper soil horizons 
Table 7 Simulated annual water balances of the Ref and W05/90 study plots, given in $\mathrm{mm}$ and as percentage of precipitation $(\% \mathrm{P})$

\begin{tabular}{lccccc}
\hline $\begin{array}{l}\text { Water balance } \\
\text { component }\end{array}$ & 2010 & & & 2011 & \\
\cline { 2 - 3 } \cline { 5 - 6 } & $\begin{array}{l}\text { Ref mm } \\
(\% \mathrm{P})\end{array}$ & $\begin{array}{l}\text { W05/90 } \mathrm{mm} \\
(\% \mathrm{P})\end{array}$ & $\begin{array}{l}\text { Ref mm } \\
(\% \mathrm{P})\end{array}$ & $\begin{array}{l}\text { W05/90 } \mathrm{mm} \\
(\% \mathrm{P})\end{array}$ \\
\hline Precipitation & $651(-)$ & $651(-)$ & & $662(-)$ & $662(-)$ \\
Interception evap. & $74(11)$ & $168(26)$ & & $85(13)$ & $168(25)$ \\
Transpiration & $161(25)$ & $219(34)$ & & $236(36)$ & $293(44)$ \\
Soil evaporation & $73(11)$ & $75(12)$ & & $80(12)$ & $77(12)$ \\
Drainage & $345(53)$ & $189(29)$ & & $264(40)$ & $172(26)$ \\
$\Delta$ Water storage & $-8(-1)$ & $-2(-0.5)$ & $19(3)$ & $-27(-4)$ \\
\hline
\end{tabular}

${ }^{\text {a }}$ Compared to initial soil water storage at $-60 \mathrm{hPa}$

of the $\mathrm{P} 94 / 30$ plot. This finding might be regarded as a development towards more resilience against mineralization pulses and unwanted releases of $\mathrm{C}$ and $\mathrm{N}$ to the atmosphere and/or water sources.

As we do not know how the nitrate concentrations developed on W94/30 since establishment in 1994, we only can speculate: a few years after SRC establishment, the biological activity of the site will increase compared to the former cropland, due to the continuous input of leaf and root litter with no respective output losses of organic material by harvesting. In addition, different vertical soil structures (such as $\mathrm{C}$ and $\mathrm{N}$ accumulations in deeper soil layers) will develop. The most obvious indication of such development is that normally no leaf litter from the previous autumn can be found in spring and $\mathrm{C}$ and $\mathrm{N}$ is higher in horizons below the plowing depth of $30 \mathrm{~cm}$.

Furthermore, $\mathrm{N}$ sources released by mineralization processes are protected from $\mathrm{N}$-leaching as long as $\mathrm{N}$ uptake by the vegetation cover is balancing the $\mathrm{N}$ release. If plant growth stops for some reason - as it was evident on plot W94/30 - but mineralization processes continue, nitrate leaching may occur. Harvesting may also stop the $\mathrm{N}$ uptake. But, since this is done normally during winter, when mineralization rates are low and the rootstock immediately resprouts once the weather gets warmer, nitrification pulses after harvest are not described so far, even in cases with additional $\mathrm{N}$ fertilization [59-61].

Comparable field data of nitrate leaching under SRC without additional $\mathrm{N}$ input manipulation $(\mathrm{N}$ fertilization, sewage sludge, waste water or compost additions) are rare. However, in one comparable study, Goodlass et al. [60] found enhanced nitrate leaching under a Salix viminals SRC, after the former canola field was plowed in winter and sprayed with herbicides in the following spring. Peak nitrate concentrations reached a maximum of $70 \mathrm{mg} \mathrm{NO} \mathrm{N}_{3}$ $\mathrm{N} \mathrm{L}^{-1}$ in spring and were even enhanced to $134 \mathrm{mg} \mathrm{NO}$ $\mathrm{N} \mathrm{L}^{-1}$ during the following autumn. Once the SRC was established, concentrations returned to a lower level $(18 \mathrm{mg}$ $\mathrm{NO}_{3}-\mathrm{N} \mathrm{L}^{-1}$ ) and were only slightly affected by harvesting operations and annual applications of nitrogen during the first 3 years. The reference plot was an adjacent arable area where nitrate peaks ranged from 26 to $77 \mathrm{mg} \mathrm{NO}_{3}-\mathrm{N} \mathrm{L}^{-1}$ with an average value of $54 \mathrm{mg} \mathrm{NO}_{3}-\mathrm{N} \mathrm{L}^{-1}$ during the crop rotation. Thus it was concluded, that once established, the risk of nitrate leaching from SRC grown at recommended $\mathrm{N}$ inputs is small, especially when compared with the nitrate peaks in autumn, which are typical of arable rotations [60]. Moreover, significant losses during establishment of stands would be offset by smaller losses during the productive phase, when compared to average nitrate losses from crop production systems [60].

\section{Land Use-Specific Water Budgets}

The water balance simulations for the Ref and W05/90 study plots revealed distinct differences in partitioning precipitation into $E_{i}, T_{a}$ and groundwater recharge. The differences in water budget partitioning are not surprising and generally agree with the findings of Persson [24], who compared the water budgets of different vegetation types and found highest evapotranspiration rates for spruce and willow and lowest for grassland and barley. However, considering the whole observation period, groundwater recharge from the willow stand was reduced by approximately $40 \%\left(120 \mathrm{~mm} \mathrm{a}^{-1}\right)$ compared to the reference site. This is comparable to values for deciduous forests at comparable sites [62], but groundwater recharge from W05/90 was higher than values reported for coniferous forests [63] located at Fuhrberger Feld. The reduction thus is smaller than the reduction reported by Persson [24] for comparable land uses and reflects the need for water balance studies including various sites and different meteorological conditions. Furthermore, studies about the water balance of willow SRC on sandy soils with low amounts of plant available soil water storage are scarce in literature and data covering the whole year and not only the growing season are even scarcer.

Groundwater recharge from the willow stand was considerably reduced in comparison with the reference plot. The main reason for this shift from groundwater recharge to evapotranspiration lies in doubled interception losses, which are caused by a closer coupling of SRC stands to the atmosphere [38]. This implies that evapotranspiration rates are mainly controlled by atmospheric vapor pressure deficit and aerodynamic resistance and less by available radiation energy [64]. Together with a higher interception storage capacity of the willow canopy, simulated interception was approximately $25 \%$ of annual precipitation in both years. This amount lies between two extremes reported by Persson and Lindroth [38] (11\%) and Ettala [65] (31\%).

It is surprising that during both years, the willow stand intercepted the same amount of rainfall $(170 \mathrm{~mm}$, Table 7) at nearly the same annual sum of precipitation, despite the fact 
that the stand was harvested in spring 2011. Re-sprouting stands are in the first half of the growing season less well coupled to the atmosphere because of their low stand height [38]. Additionally, leaf area development is delayed compared to a mature stand. This implies a lower canopy interception storage capacity and before canopy closure, a higher amount of precipitation directly reaches the ground. Thus, it is conceivable that the harvested willow stand intercepts relatively less rainfall than a mature stand, and the lack of differences between the years is due to a different temporal distribution of rainfall. In fact, a simulation scenario that assumes a mature instead of a re-sprouting willow stand under the climate conditions of 2011 yields interception losses increased by $25 \mathrm{~mm}$. In turn, a re-sprouting stand under the 2010 climate conditions has $15 \mathrm{~mm}$ less interception evaporation per year.

Aside from interception evaporation, transpiration rates from the willow stand are as well higher than transpiration rates from the reference site. With a deeper rooting system, the willow stand draws water from a greater soil volume, thus more water is available for transpiration. In both years, annual transpiration from the willow stand was approximately $60 \mathrm{~mm}$ higher compared to the reference site. This amount complies well with the surplus of plant available soil water resources. Tensiometer time series (Fig. 2b) indicate that the investigated willow SRC is able to evapotranspirate all precipitation that falls during the growing season (also see [18]) and additionally develops pronounced soil water deficits. These soil water deficits-being about $60 \mathrm{~mm}$ higher compared to the reference plot - in turn reduce the groundwater recharge, as the soil needs to be rewetted before drainage can take place.

A consequence of the willows' high water demand in combination with the relatively low soil water storage capacity of the sandy soils is the exposition to water stress during periods with low amounts of precipitation. This is exactly what the simulation suggested in July 2010, when transpiration collapsed (Fig. 3b) because of exhausted soil water supplies in the root zone. Typical reactions to water stress are leaf shedding [66, 67] and yield losses [18]. Leaf shedding was actually observed on the study plot in July 2010. Yield was not monitored during or immediately after the drought, but mean annual dry mass production at the end of the year 2009 was approximately $5.7 \mathrm{Mg} \mathrm{ha}^{-1}$ [28]. This value is relatively low for willow SRCs [18] and indicates that growth conditions are not optimal in the Fuhrberger Feld, likely due to repeated water shortage.

Higher amounts of plant available soil water, either due to a higher soil water storage capacity as found in loamy soils, a greater rooting depth or even direct access to groundwater help to bridge extended dry periods and in terms of yield lead to more robust SRC production systems. However, this increased robustness is at the expense of groundwater recharge, since the soil water storage has to be refilled before drainage can form. Therefore, it can be concluded, that on sites with low plant available soil water capacity and where roots have no access to the water table, a change in land use from fallow to SRC indeed will have a negative impact on groundwater recharge. But on such sites, this impact is, as long as SRCs do not have access to groundwater, moderate: The soil water storage capacity sets a minimum level for groundwater recharge, but also sets the maximum limit to yield.

\section{$\mathrm{N}$ released by Nitrate Leaching}

Nitrate fluxes from the reference (Ref) and the willow (W05/90) plot (Table 8) were calculated from the simulated drainage fluxes. Mean concentrations for all sampling dates were multiplied with the corresponding drainage flux during the sampling interval, nitrate fluxes were cumulated separately for periods A (Feb 2010 to May 2010) and B (Dec 2010 to June 2011). In order to obtain an estimate of the annual nitrate output rate for the year 2010, nitrate seepage concentrations for the months Sep to Nov 2010, where considerable amounts of drainage from Ref took place but concentration measurements were missing, were assumed to be the same as in Dec 2010. For the summer months in 2010, when also no samples could be taken and only minimal drainage occurred, the concentrations measured in May were used to calculate the nitrate flux.

In total, the $\mathrm{W} 05 / 90$ plot lost $16.5 \mathrm{~kg} \mathrm{NO}_{3}-\mathrm{N} \mathrm{ha}^{-1} \mathrm{a}^{-1}$ in 2010 (Table 8), where $87 \%$ of the losses happened during winter/spring 2010. Nitrate leaching from the reference plot (Ref) was less than a tenth $\left(1.36 \mathrm{~kg}\right.$ of $\left.\mathrm{NO}_{3}-\mathrm{N} \mathrm{ha}^{-1} \mathrm{a}^{-1}\right)$ of the amount of the SRC plot. Eighty percent of the annual leaching from Ref occurred during winter and spring 2010.

Calculated nitrate leaching losses for the W05/90 plot are slightly higher than reported in previous studies [59, 61]. There, leaching rates were between zero and slightly less than $2 \mathrm{~kg} \mathrm{ha}^{-1} \mathrm{a}^{-1}$, despite long-term repeated annual nitrogen fertilization of more than $150 \mathrm{~kg} \mathrm{ha}^{-1} \mathrm{a}^{-1}$ [59]. However, our rates were about 10 times lower than rates cited by Aronsson and Bergström [59] for the first year after establishment, when

Table 8 Cumulated drainage water fluxes and nitrate leaching loss ( $\pm \mathrm{SD}$ ) for the Ref and $\mathrm{W} 05 / 90$ study plots during sampling periods A (Feb 2010-May 2010) and B (Dec 2010 -June 2011), as well as the annual sum for 2010

\begin{tabular}{llllll}
\hline & \multicolumn{2}{l}{ Drainage flux $\left(\mathrm{L} \mathrm{m}^{-2}\right)$} & & \multicolumn{2}{l}{ Nitrate leaching $\left(\mathrm{kg} \mathrm{ha}^{-1}\right)$} \\
\cline { 2 - 3 } \cline { 6 - 6 } & Ref & W05/90 & & Ref & W05/90 \\
\hline Period A & 171 & 143 & & $1.08 \pm 0.85$ & $14.3 \pm 6.55$ \\
Period B & 216 & 180 & & $0.42 \pm 0.38$ & $2.03 \pm 1.46$ \\
Jan-Dec 2010 & 345 & 189 & & $1.36 \pm 1.08$ & $16.5 \pm 7.95$ \\
\hline
\end{tabular}


willow was cultivated in lysimeters, highly fertilized and irrigated on sandy soils $\left(140 \mathrm{~kg} \mathrm{NO}_{3}-\mathrm{N} \mathrm{ha}^{-1} \mathrm{a}^{-1}\right)$. Similar $\mathrm{N}$ loss with seepage of $90 \mathrm{~kg} \mathrm{NO}_{3}-\mathrm{N} \mathrm{ha}^{-1} \mathrm{a}^{-1}$ were measured by Dimitriou and Aronsson [68] from a lysimeter experiment, where irrigated willows in sandy soil were fertilized with $320 \mathrm{~kg}$ of $\mathrm{N} \mathrm{ha}^{-1}$ in form of sewage sludge. These losses occurred within a time span of 6 months (May to Oct) and were mainly attributed to the high $\mathrm{N}$ fertilizer input and not to the chemical composition of the fertilizers. As in our study, almost $90 \%$ of the annual leaching from the W05/90 plot happened during the winter/spring 2010 there might be some site specific but until now unknown reason for a relatively high leaching flush. No direct $\mathrm{N}$ input by fertilization or any comparable input occurred and possible mineralization artifacts potentially produced by the installation of the suction lysimeters can also be excluded, since they were installed 4 months earlier.

Increased nitrate leaching may also favor $\mathrm{N}_{2} \mathrm{O}$ emissions [69]. As part of a Diploma thesis, a series of five $\mathrm{N}_{2} \mathrm{O}$ measurement campaigns between June and Oct 2010 was conducted on all plots, except for W94/30 [70]. Results indicate that $\mathrm{N}_{2} \mathrm{O}$ emissions increased after heavy rainfalls at the end of August and in September 2010 at the P09/90 plot. Here, maximum mean values in August reached emissions of 65.0 $( \pm 20.5 \mathrm{SD}) \mu \mathrm{g} \mathrm{N}_{2} \mathrm{O}-\mathrm{N} \mathrm{m}^{-2} \mathrm{~h}^{-1}$, but values fell back to a baseline of below $20 \mu \mathrm{g} \mathrm{N}_{2} \mathrm{O}-\mathrm{N} \mathrm{m}^{-2} \mathrm{~h}^{-1}$ in October 2010 again. However, also the reference plot showed peak values during this period (August 2010: 43.5 $\pm 18.6 \mathrm{SD} \mu \mathrm{g} \mathrm{N} \mathrm{N}_{2} \mathrm{O}$ $\mathrm{N} \mathrm{m}^{-2} \mathrm{~h}^{-1}$ ), whereas the $\mathrm{W} 05 / 90$ and P $94 / 30$ plots never had higher emissions than $20 \mu \mathrm{g} \mathrm{N} \mathrm{N}_{2} \mathrm{O}-\mathrm{N} \mathrm{m}^{-2} \mathrm{~h}^{-1}$ [70]. In agreement with other studies [71, 72], it is concluded that SRC, once established, emit considerably less $\mathrm{N}_{2} \mathrm{O}$, compared to other bioenergy crops or even less than fallow grounds [70]. Estimated annual emission rates for the established SRC plots in the Fuhrberger Feld were below $1 \mathrm{~kg} \mathrm{ha}^{-1} \mathrm{a}^{-1}[70]$.

\section{Conclusions}

Former cropland which was abandoned due to protection reasons of nitrate pollution in lowland drinking water catchment areas can well be used for the cultivation of SRC to increase the land use value by the production of woody biomass. Our results showed that in SRCs of willow and poplar clones with different age (2-17 years) and different soil preparation measures (standard and deep plowing), the mean nitrate concentrations in $100 \mathrm{~cm}$ soil depth with few exceptions stays below the drinking water threshold value of $10.3 \mathrm{mg} \mathrm{NO}-\mathrm{N} \mathrm{L}^{-1}$. There are two stages, where relatively increased amounts of nitrate might be leached from SRC cultivations, i.e., (1) when SRC are newly installed and intensive or even deep plowing was applied before cultivation (example P09/90) and (2) when the sink, respectively the export function for $\mathrm{N}$ compounds by tree uptake and harvesting measures is offset (example W94/30). Harvesting itself obviously did not initiate a nitrate flush, but nitrate release from an over-aged, never harvested willow stand was significantly increased.

Furthermore, we conclude that groundwater recharge rates, which are also of concern in drinking water sanctuaries, were not excessively reduced by SRC cultivations. Soils with low amounts of plant available soil water storage capacity and high permeability, as often found in lowland drinking water catchment areas, set a minimum level for groundwater recharge by limiting transpiration, as long as roots have no access to the groundwater table. Thus, less precipitation is needed to refill the soil water storage than on soils with higher water storage capacity, and groundwater recharge begins earlier after transpiration ceases in autumn.

Another finding, which needs more investigation though, might provide an opportunity to manipulate the water balance of SRC stands by management. Less interception loss can be expected from stands during the first year after harvested and thus higher groundwater recharge rates might be obtained by choosing a shorter rotation cycle, as the stand then is more often in the resprouting state.

Acknowledgments The authors are grateful to the Hanover water authorities (Stadtwerke Hannover AG; www.enercity.de), to the Agency for Renewable Resources (FNR e.V; . www.fnr.de) and to the European ERA-NET-Bioenergy program (www.eranetbioenergy.net) for funding this study. We give our special thanks to D. Böttger for his field assistance, P.-E. Jansson for his valuable hints and suggestions concerning the water balance simulations and O. van Straaten for correcting grammar and spelling of the manuscript.

Open Access This article is distributed under the terms of the Creative Commons Attribution License which permits any use, distribution, and reproduction in any medium, provided the original author(s) and the source are credited.

\section{References}

1. IEA (2010) IEA statistics - renewables information 2010. Technical report. IEA, Paris, p 446

2. European Council (2009) Directive 2009/28/EC of the European Parliament and of the Council of 23 April 2009 on the promotion of the use of energy from renewable sources and amending and subsequently repealing Directives 2001/77/EC and 2003/30/EC. Technical report

3. EEA (2006) How much bioenergy can Europe produce without harming the environment? Technical report. European Environment Agency, Copenhagen

4. European Union (2007) The impact of a minimum $10 \%$ obligation for biofuel use in the EU-27 in 2020 on agricultural markets. Technical report

5. FNR (2011) www.nachwachsenderohstoffe.de/service/daten-undfakten/anbau, access: 21.11.2011. Technical report, Fachagentur Nachwachsende Rohstoffe e.V. (FNR), 18276 Gülzow-Prüzen, Germany 
6. Don A, Osborne B, Hastings A, Skiba U, Carter MS, Drewer J et al (2011) Land-use change to bioenergy production in Europe: implications for the greenhouse gas balance and soil carbon. GCB Bioenergy 4(4):372-391

7. Djomo SN, Kasmioui OE, Ceulemans R (2011) Energy and greenhouse gas balance of bioenergy production from poplar and willow: a review. GCB Bioenergy 3(3):181-197

8. Buhler DD, Netzer DA, Riemenschneider DE, Hartzler RG (1998) Weed management in short rotation poplar and herbaceous perennial crops grown for biofuel production. Biomass Bioenergy 14 (4):385-394

9. Otto S, Loddo D, Zanin G (2010) Weed-poplar competition dynamics and yield loss in italian short-rotation forestry. Weed Res 50(2):153-162

10. Röhle H, Böcker L, Feger K-H, Petzold R, Wolf H, Ali W (2008) Anlage und Ertragsaussichten von Kurzumtriebsplantagen in Ostdeutschland. Schweiz Z Forstwes 159:133-139

11. Crutzen PJ, Mosier AR, Smith KA, Winiwarter W (2008) $\mathrm{N}_{2} \mathrm{O}$ release from agro-biofuel production negates global warming reduction by replacing fossil fuels. Atmos Chem Phys 8 (2):389-395

12. Well R, Butterbach-Bahl K (2010) Indirect emissions of nitrous oxide from nitrogen deposition and leaching of agricultural nitrogen. In: Smith K (ed) Nitrous oxide and climate change. Earthscan Publications Ltd., Sterling, UK, p 162

13. Pape JC (1970) Plaggen soils in the Netherlands. Geoderma 4:229255

14. Springob G, Brinkmann S, Engel N, Kirchmann H, Böttcher J (2001) Organic C levels of Ap horizons in north german pleistocene sands as influenced by climate, texture, and history of landuse. J Plant Nutr Soil Sci 164:681-690

15. Springob G, Kirchmann H (2010) Ratios of carbon to nitrogen quantify non-texture-stabilized organic carbon in sandy soils. J Plant Nutr Soil Sci 173(1):16-18

16. Köhler K, Duijnisveld WHM, Böttcher J (2006) Nitrogen fertilization and nitrate leaching into groundwater on arable sandy soils. J Plant Nutr Soil Sci 169:185-195

17. Petzold R, Schwärzel K, Feger K-H (2011) Transpiration of a hybrid poplar plantation in saxony (Germany) in response to climate and soil conditions. Eur J For Res 130:695-706

18. Lindroth A, Båth A (1999) Assessment of regional willow coppice yield in Sweden on basis of water availability. For Ecol Manag 121 (1-2):57-65

19. Grip H, Halldin S, Lindroth A (1989) Water use by intensively cultivated willow using estimated stomatal parameter values. Hydrol Process 3(1):51-63

20. Hall RL, Allen SJ, Rosier PTW, Hopkins R (1998) Transpiration from coppiced poplar and willow measured using sap-flow methods. Agric For Meteorol 90:275-290

21. Knur L, Murach D, Murn Y, Bilke G, Muchin A, Grundmann P, et al. (2007) Potentials, economy and ecology of a sustainable supply with wooden biomass. In: From research to market development: 15th European Biomass Conference \& Exhibition proceedings of the international conference held in Berlin

22. Lamersdorf N, Schulte-Bisping H (2010) Zum Wasserhaushalt von Kurzumtriebsplantagen. Archiv für Forstwesen und Landschaftsökologie 44:23-29

23. Lindroth A, Verwijst T, Halldin S (1994) Water-use efficiency of willow: variation with season, humidity and biomass allocation. $\mathrm{J}$ Hydrol 156(1-4):1-19

24. Persson G (1997) Comparison of simulated water balance for willow, spruce, grass ley, and barley. Nord Hydrol 28:85-89

25. Dimitriou I, Busch G, Jacobs S, Schmidt-Walter P, Lamersdorf N (2009) A review of the impacts of short rotation coppice cultivation on water issues. vTI Agric For Res 3:197-206
26. Jansson P-E, Karlberg L (2004) Coupled heat and mass transfer model for soil-plant-atmosphere systems. Technical report, Royal Institute of Technolgy, Dept of Civil and Environmental Engineering Stockholm, Stockholm. ftp://www.lwr.kth.se/CoupModel/ CoupModel.pdf

27. TrinkwV (2011) Trinkwasserverordnung (TrinkwV) Deutschland, in der Fassung der Bekanntmachung vom 28. (BGBl. I S. 2370), 2001

28. Techtmann C (2010) Wuchsleistung von Weiden und Pappeln im Kurzumtrieb auf ertragsschwachen Standorten. Master's thesis, University of Göttingen

29. ICP (2004) Subprogramm sw: soil water chemistry. Technical report, ICP

30. Fürst A (2012) 14th needle/leaf interlaboratory comparison test 2011/2012. Technical report

31. ICP (2011) ICP Waters Report 107/2011, Intercomparison 1125. Technical report, ICP

32. Schlichting E, Blume HP, Stahr K (1995) Bodenkundliches Praktikum. Blackwell Wissenschaft, Berlin

33. Wegehenkel M (2005) Validation of a soil water balance model using soil water content and pressure head data. Hydrol Process 19 (6):1139-1164

34. Pinheiro JC, Bates DM (2000) Linear mixed effects models in S and S-PLUS, chapter linear mixed effects models. Springer, Berlin, pp 3-56

35. Akaike H (1973) Information theory and an extension of maximum likelihood principle. In: Petrov BN, Csaki F (eds) Second international symposium on information theory, vol 1. Akademiai Kiado, Budapest, pp 267-281

36. Pinheiro JC, Bates DM, DebRoy S, Sarkar D, R Development Core Team (2012) NLME: linear nonlinear mixed effect model $3: 1-103$, R package version

37. R Development Core Team. R: a language and environment for statistical computing. R Foundation for Statistical Computing, Vienna, Austria, 2011. URL http://www.R-project.org/. ISBN 3900051-07-0

38. Persson G, Lindroth A (1994) Simulating evaporation from shortrotation forest: variations within and between seasons. J Hydrol 156(1-4):21-45

39. Heidmann T, Thomsen A, Schelde K (2000) Modelling soil water dynamics in winter wheat using different estimates of canopy development. Ecol Model 129:229-243

40. Christiansen JR, Elberling B, Jansson P-E (2006) Modelling water balance and nitrate leaching in temperate Norway spruce and beech forests located on the same soil type with the CoupModel. For Ecol Manag 237(1-3):545-556

41. Jansson P-E, Cienciala E, Grelle A, Kellner E, Lindahl A, Lundblad M (1999) Simulated evapotranspiration from the Norunda forest stand during the growing season of a dry year. Agric For Meteorol 98-99:621-628

42. Lundmark A (2008) Monitoring transport and fate of de-icing salt in the roadside environment-Modelling and field measurements. $\mathrm{PhD}$ thesis, Kungliga Tekniska högskolan-Land and Water Resources Engineering, Stockholm

43. Brooks RH, Corey AT (1966) Properties of porous media affecting fluid flow. J Irrig Drain Div Proc Am Soc Civ Eng (IR2) 92:61-88

44. Mualem Y (1976) A new model for predicting the hydraulic conductivity of unsaturated porous media. Water Resour Res 12:513-522

45. Monteith JL (1965) Evaporation and environment. Symp Soc Exp Biol 19:205-224

46. Lindroth A (1985) Canopy conductance of coniferous forests related to climate. Water Resour Res 21:297-304

47. Shaw RH, Pereira AR (1982) Aerodynamic roughness of a plant canopy: a numerical experiment. Agric Meteorol 26:51-65 
48. Crow P, Houston TJ (2004) The influence of soil and coppice cycle on the rooting habitat of short rotation poplar and willow coppice. Biomass Bioenergy 26:497-505

49. Thrän D, Edel M, Seidenberger T (2009) Identifizierung strategischer Hemmnisse und Entwicklung von Lösungsansätzen zur Reduzierung der Nutzungskonkurrenzen beim weiteren Ausbau der energetischen Biomassenutzung. 1. Zwischenbericht. Technical report, Deutsches Biomasseforschungszentrum (DBFZ)

50. Hajkova Z (2011) Pappeln mit neuen Methoden züchten. Gesunde Pflanzen Mitteilungen aus der Presse 63:205-209. doi:10.1007/ s10343-011-0267-5

51. Fritsche UR, Hennenberg KJ, Wiegeman K, Herrera R, Franke B, Köppen S, et al. (2010) Bioenergy environmental impact analysis (bias): analytical framework. Technical report

52. Busch G (2009) The impact of short rotation coppice cultivation on groundwater recharge - a spatial (planning) perspective. Landbauforschung - vTI Agric For Res 3(59):207-222

53. Baum S, Weih M, Busch G, Kroiher F, Bolte A (2009) The impact of short rotation coppice plantations on phytodiversity. Landbauforschung - vTI Agric For Res 3(59):163-170

54. Schulz U, Brauner O, Gruß H (2009) Animal diversity on shortrotation coppices - a review. vTI Agric For Res 59(3):171-181

55. Scholz VG, Heiermann M, Kern J, Balasus A (2011) Environmental impact of energy crop cultivation. Umweltwirkungen des Energiepflanzenanbaus. Arch Agron Soil Sci 57:1-33

56. Weih M, Karacic A, Munkert H, Verwijst T, Diekmann M (2003) Influence of young poplar stands on floristic diversity in agricultural landscapes (Sweden). Basic Appl Ecol 4:149-156

57. WFD (2000) Water Framework Directive 2000/60/EC of the European Parliament and of the Council establishing a framework for the Community action in the field of water policy

58. Gadgil M, Ranjit Daniels RJ, Ganeshaiah KN, Narendra Prasad S, Murthy MSR, Jha CS et al (2011) Mapping ecologically sensitive, significant and salient areas of western ghats: proposed protocols and methodology. Curr Sci 100(2):175-182

59. Aronsson PG, Bergström LF, Elowson SNE (2000) Long-term influence of intensively cultured short-rotation willow coppice on nitrogen concentrations in groundwater. Aust J Environ Manag 58(2):135-145

60. Goodlass G, Green M, Hilton B, McDonough S (2007) Nitrate leaching from short-rotation coppice. Soil Use Manag 23(2):178-184
61. Mortensen J, Nielsen KH, JØrgensen U (1998) Nitrate leaching during establishment of willow (Salix viminalis) on two soil types and at two fertilization levels. Biomass Bioenergy 15(6):457-466

62. Müller J (1996) Beziehungen zwischen Vegetationsstrukturen und Wasserhaushalt in Kiefern- und Buchenökosystemen. Mitteilungen der Bundeforschungsanstalt Forst- und Holzwirtschaft 185:112122

63. Renger M, Strebel O, Wessolek G, Duynisveld WHM (1986) Evapotranspiration and groundwater recharge - a case study for different climate, crop patterns, soil properties, and groundwater depth conditions. J Plant Nutr Soil Sci 149:371-381

64. Jarvis PG (1985) Coupling of transpiration to the atmosphere in horticultural crops: the omega factor. Acta Horticult 171:187-205

65. Ettala M (1988) Evapotranspiration from a Salix aquatica plantation at a sanitary landfill. Aqua Fennica 18:3-14

66. Linderson M-L, Iritz Z, Lindroth A (2007) The effect of water availability on stand-level productivity, transpiration, water use efficiency and radiation use efficiency of field-grown willow clones. Biomass Bioenergy 31(7):460-468

67. Weih M (2001) Evidence for increased sensitivity to nutrient and water stress in a fast-growing hybrid willow compared with a natural willow clone. Tree Physiol 21:1141-1148

68. Dimitriou I, Aronsson P (2004) Nitrogen leaching from shortrotation willow coppice after intensive irrigation with wastewater. Biomass Bioenergy 26(5):433-441

69. Zechmeister-Boltenstern S, Hahn M, Meger S, Jandl R (2002) Nitrous oxide emissions and nitrate leaching in relation to microbial biomass dynamics in a beech forest soil. Soil Biol Biochem 34 (6):823-832

70. Wolf $\mathrm{R}$ (2011) Freisetzung von Spurengasen $\left(\mathrm{CO}_{2}, \mathrm{CH}_{4}\right.$ und $\left.\mathrm{N}_{2} \mathrm{O}\right)$ und Kohlenstoffakkumulation in Kurzumtriebsplantagen im Fuhrberger Feld. Master's thesis, University of Göttingen

71. Drewer J, Finch JW, Lloyd CR, Baggs EM, Skiba U (2011) How do soil emissions of $\mathrm{N}_{2} \mathrm{O}, \mathrm{CH}_{4}$ and $\mathrm{CO}_{2}$ from perennial bioenergy crops differ from arable annual crops? GCB Bioenergy 4(4):408419

72. Gauder M, Butterbach-Bahl K, Graeff-Hönninger S, Claupein W, Wiegel R (2011) Soil-derived trace gas fluxes from different energy crops - results from a field experiment in Southwest Germany. GCB Bioenergy 4(3):289-301 